\title{
PUBLICACIONES SOBRE FILOLOGÍA GRIEGA EN ESPAÑA
} (2011)

\author{
Helena RodRíGuez Somolinos \\ CCHS. CSIC. Madrid \\ helena.rsomolinos@cchs.csic.es
}

\section{RESUMEN}

Bibliografía relativa a Filología Griega publicada en España en 2011.

PAlABRAS Clave: Filología Griega; Bibliografía: España

\section{Abstract}

Bibliography concerning Greek Philology published in Spain in 2011.

KEY WORDS: Greek Philology; Bibliography: Spain

\section{ORgANIZACIÓN}

I. ACtas de Congresos. Homenajes. Volúmenes colectivos

2. Autores antiguos. Ediciones, traducciones y ESTUdios

3. Historia De la literatura

4. Lingüística GRIEga. MÉtrica

5. Micenología

6. Epigrafía. Papirología. Numismática

7. Historia de los textos

8. Historia. Cultura. Sociedad 

9. Religión. Mitología
io. Cristianismo
i i. Filosofía. Ciencia
i 2. Pervivencia. Humanismo. Historia de la filología
I3. Diccionarios. Repertorios. Otros instrumentos
I4. DidÁCTICA

REVISTAS

$A E A$

Archivo Español de Arqueología. Madrid, CSIC, Centro de Estudios Históricos. Dpto. de Arqueología y Prehistoria. http://aespa.revistas.csic.es/index.php/aespa

AEF Anuario de Estudios Filológicos. Cáceres. Universidad de Extremadura. Facultad de Filosofía y Letras. http://www.unex.es/organizacion/servicios/servicio_publicaciones/ publicaciones/anuario-de-estudios-filolagicos-vols-i-xxx-2007

AM Analecta Malacitana. Universidad de Málaga. Facultad de Filosofía y Letras. Sección de Filología. http://www.anmal.uma.es/

AM-E Analecta Malacitana Electrónica. Universidad de Málaga. Facultad de Filosofía y Letras. Sección de Filología. http://www.anmal.uma.es/

Arys. Arys. Antigüedad: religiones y sociedades. Universidad de Huelva. Servicio de Publicaciones. http://www.uhu.es/publicaciones/ojs/index. php/arys

AuOr Aula Orientalis. Revista de Estudios del Próximo Oriente Antiguo. Institut Interuniversitari d'Estudis del Pròximo Orient Antic. Sabadell (Barcelona). Editorial Ausa. http://www.aulaorientalis.org/

Cal.Ren. Calamus Renascens. Revista de Humanismo y tradición clásica. Alcañiz. Instituto de Estudios Humanísticos.

http://www.estudioshumanisticos.org/publicaciones.php

CCO Collectanea Christiana Orientalia. Universidad de Córdoba. Facultad de Filosofía y Letras. http://www.uc.es/collectanea

CFCG Cuadernos de Filología Clásica. Estudios Griegos e Indoeuropeos. Universidad Complutense de Madrid. Facultad de Filología. http://revistas.ucm.es/index.php/CFCG

CFCL Cuadernos de Filología Clásica. Estudios Latinos. Universidad Complutense de Madrid. Facultad de Filología. http://revistas.ucm.es/index. php/CFCL

EB Estudios Bíblicos. Madrid. Universidad San Dámaso - Asociación Bíblica Española. http://www.sandamaso.es/publicaciones_detalle. php?id=967\&cat_nombre=Revistas\&s cat_nombre $=$ Estudios $\% 20$ B\%EDblicos

EC Exemplaria Classica. Departamento de Filologías Integradas. Facultad de Humanidades. Universidad de Huelva.

http://www.uhu.es/publicaciones/ojs/index.php/exemplaria/index 
EClás.

EH

$E L E A$

Emerita

Epos

Faventia

FI

$F N$

Fortunatae

Gallaecia

Gerión

Habis

HAnt.

Helmantica

Iberia

'Ilu
Estudios Clásicos. Madrid, Sociedad Española de Estudios Clásicos. http://interclassica.um.es/investigacion/hemeroteca/e/estudios_clasicos Estudios Humanísticos. Filología. Universidad de León. Facultad de Filosofía y Letras.

http://www.filosofiayletras.unileon.es/investigacion/estudios_humanisticos_filologia.html

Estudios de Lenguas y Epigrafía Antiguas. Valencia. Real Academia de Cultura Valenciana. http://www.racv.es/info_coleccio_llibres/361

Emerita. Revista de Lingüística y Filología Clásica. Madrid. C.S.I.C. Centro de Ciencias Humanas y Sociales. Instituto de Lenguas y Culturas del Mediterráneo y Oriente Próximo.

http://emerita.revistas.csic.es/index.php/emerita

Epos. Revista de Filología. Madrid. Universidad Nacional de Educación a Distancia. Facultad de Filología.

http://e-spacio.uned.es:8080/fedora/get/bibliuned:revistaEPOS/ demo:Collection/view/

Faventia. Universitat Autònoma de Barcelona. Facultat de Lletres. Dpto. de Filología Clásica. http://ddd.uab.es/record/21?ln=ca

Florentia Iliberritana. Revista de Estudios de Antigüedad Clásica. Universidad de Granada. http://www.ugr.es/ hantigua/florentia.html Filología Neotestamentaria. Universidad de Córdoba. Facultad de Filosofía y Letras. http://www.bsw.org/Filologia-Neotestamentaria/

Fortunatae. Revista canaria de filología, cultura y humanidades clásicas. Universidad de la Laguna. Departamento de Filología Clásica y Arabe. http://www.clasicasyarabeull.org/modules.php?name=Content $\& \mathrm{pa}=\mathrm{sh}$ owpage\&pid=1

Gallaecia. Universidad de Santiago de Compostela. Departamento de Historia I. http://www.usc.es/ troia/revis_gallaecia.html

Gerión. Universidad Complutense de Madrid. Departamento de Historia Antigua. http://revistas.ucm.es/index.php/GERI

Habis. Universidad de Sevilla. Departamentos de Filología Clásica, Historia Antigua y Prehistoria y Arqueología. http://institucional.us.es/habis/ Hispania Antiqua. Revista de Historia Antigua. Universidad de Valladolid. Depto. de Historia Antigua. http://www.publicaciones.uva.es/ Buscador. aspx?txtBusqueda=HISPANIA\%20ANTIQ\&txtFamilia= Humanidades $\% 20 / \% 20$ Revistas

Helmantica. Revista de Filología Clásica y Hebrea. Universidad Pontificia de Salamanca.

https://www.intranet.upsa.es/publica/publicaciones. pl?method $=$ detalleRevista\&id $=4$

Iberia. Revista de la Antigüedad. Universidad de La Rioja. http://www.unirioja.es/servicios/sp/revistas/iberia.shtml

'Ilu. Revista de Ciencias de las Religiones. Universidad Complutense de Madrid. Instituto Universitario de Ciencias de las Religiones.

http://revistas.ucm.es/index.php/ILUR 
Ítaca

Lucentum

Methodos

MHNH

Minerva

Myrtia

Palaeohispanica

Paremia

Ph.Canar.

Polis

Pyrenae

R.S.E.L.

$R P L$

SEBarc.

SPhV

Thamyris
Ítaca. Quaderns Catalans de Cultura Clàsica. Barcelona. Institut d' Estudis Catalans. http://publicacions.iec.cat/PopulaFitxa.do?moduleName=revistes_ cientifiques\&subModule Name $=\&$ idColleccio $=58$

Lucentum. Anales de Prehistoria, Arqueología e Historia Antigua. Universidad de Alicante. http://rua.ua.es/dspace/handle/10045/1110

Methodos. Revista de didàctica dels estudis clàssics. Paideia. Grup de Didàctica de les Llengües i la Cultura Clàssiques. Universitat Autònoma de Barcelona. http://pagines.uab.cat/methodos/

$M H N H$. Revista internacional de investigación sobre Magia y Astrología antiguas. Málaga, Centro de Ediciones de la Diputación de Málaga. http://webdeptos.uma.es/dep_griego/MHNH/index.htm

Minerva. Revista de Filología Clásica. Universidad de Valladolid. Departamento de Filología Clásica. http://minerva.blogs.uva.es/ Myrtia. Universidad de Murcia. http://revistas.um.es/myrtia/index

Palaeohispanica. Revista sobre lenguas y culturas de la Hispania Antigua. Zaragoza. Institución Fernando el Católico. http://ifc.dpz.es/publicaciones/periodica/id/18

Paremia. Boletín de Investigaciones Paremiológicas. Madrid. Asociación Cultural Independiente (Sigüenza) - Universidad Complutense. Sersa Ediciones. http://www.paremia.org/

Philologica Canariensia. Universidad de Las Palmas de Gran Canaria. Facultad de Filología.

http://www.ff.ulpgc.es/index.php?option=com_content\&view=article $\&$ id $=114 \&$ Itemid $=164$

Polis. Revista de ideas y formas políticas de la Antigüedad Clásica. Universidad de Alcalá de Henares. http://dspace.uah.es/dspace/handle/10017/5291 Pyrenae. Revista de Prehistòria i Antiguitat de la Mediterrània Occidental. Barcelona. Universitat de Barcelona. Facultat de Geografia i Història. Departament de Prehistòria, Història Antiga y Arqueologia. http://www.ub.edu/pyrenae/indexnet.htm

Revista Española de Lingüística. Organo de la Sociedad Española de Lingüística. Madrid. http://www.sel.edu.es/?q=node/66

Res Publica Litterarum. Documentos de trabajo del Grupo de Investigación Nómos. Universidad Carlos III de Madrid. Instituto de Estudios Clásicos sobre la Sociedad y la Política Lucio Anneo Séneca. http://www.uc3m.es/portal/page/portal/inst_lucio_anneo_seneca

Sylloge Epigraphica Barcinonensis. Universitat de Barcelona. http://www.raco.cat/index.php/SEBarc/index Studia Philologica Valentina. Universidad de Valencia. http://interclassica.um.es/index.php/interclassica/investigacion/ hemeroteca/s/studia_philologica_valentina

Thamyris. Nova series. Revista de Didáctica de Cultura Clásica. Delegación de Málaga de la S.E.E.C. - Departamentos de Filología Griega y Latina de la Universidad de Málaga. http://www.thamyris.uma.es 
Veleia Veleia. Revista de Prehistoria, Historia Antigua, Arqueología y Filología Clásica. Vitoria. Universidad del País Vasco. Instituto de Ciencias de la Antigüedad.

http://www.argitalpenak.ehu.es/p291-content/es/contenidos/libro/se_ indice_revista_veleia/ es_revista/indice_veleia.html

Zephyrus Zephyrus. Revista de Prehistoria e Historia Antigua. Universidad de Salamanca. http://campus.usal.es/ preharq/zephyrus.htm

\section{Actas de Congresos. Homenajes. Volúmenes colectivos}

AA.VV.: El narrador como hombre de acción: la construcción de la memoria colectiva en el mundo grecorromano. Salamanca, Universidad, 2011 (= Studia Historica. Historia antigua 29).

AA.VV.: «Palabras bien dichas»: Estudios filológicos dedicados al P. Pius-Ramon Tragan. Barcelona, Publicacions de l'Abadia de Montserrat, 2011 (= Palabras bien dichas).

Almela, M. - Guzmán, H. - Leguen, B. - Sanfilippo, M. (coords.): Tejiendo el mito. Madrid, Universidad Nacional de Educación a Distancia, 2011 (= Tejiendo el mito).

Belmonte, J.A. - Oliva, J. (eds.): Convivencia e interacción en las sociedades del Oriente y del Mediterráneo antiguos. V Congreso Español de Antiguo Oriente Próximo (Toledo, 26-30 de Octubre de 2009). Cuenca, Universidad de Castilla - La Mancha, 2011 (= Convivencia e interacción).

Bernabé, A. - Kahle, M. - SAntamaríA, M.Á. (EDS.): Reencarnación. La transmigración de las almas entre Oriente y Occidente. Madrid, Abada, 2011 (= Reencarnación).

Bernabé, A. - Pérez de Tudela, J. (eds.): Mitos sobre el origen del hombre. Madrid, Círculo de Bellas Artes, 2011 (= Mitos sobre el origen del hombre).

Bravo, G. - González Salinero, R. (eds.): Propaganda y persuasión en el Mundo Romano. Actas del VIII coloquio de la Asociacion interdisciplinar de estudios romanos celebrado en Madrid los días 1 y 2 de diciembre de 2010. Madrid, Signifer, 2011 (= Propaganda y persuasión).

Calderón Dorda, E. - Morales Ortiz, A. (eds.): Eusebeia. Estudios de religión griega. Madrid, Signifer, 2011 (= Eusebeia. Estudios de religión griega).

Candau Morón, J.M. - González, F.J. - Chávez, A.L. (eds.): Plutarco transmisor. Actas del X simposio internacional de la Sociedad Española de Plutarquistas (Sevilla, 12-14 noviembre de 2009). Sevilla, Universidad, 2011 (= Plutarco transmisor).

Cortés Copete, J.M. - MuÑIz Grijalbo, R. - Gordillo, R. (eds.): Grecia ante los imperios. V Reunión de historiadores del mundo griego. Sevilla, Universidad, 2011 (= Grecia ante los imperios).

Duplá Ansuategui, A. (ED.): El cine de romanos en el siglo XXI. Vitoria, Universidad del País Vasco, 2011 (= El cine de romanos en el siglo XXI).

Estudios Nietzsche. Revista Internacional de Filosofía. Sociedad Española de Estudios sobre Friedrich Nietzsche. Universidad de Málaga. http://www.estudiosnietzsche.org. Número 11 (2011) dedicado a Nietzsche y los griegos (= Estudios Nietzsche 11, 2011).

FERNÁNDEZ DE MIER, E. - Cortés Martín, J. (EDS.): Imágenes modernas del mundo antiguo. Reconstrucción, representación y manipulación de la antigüedad grecolatina en el mundo moderno. Madrid, Sociedad Española de Estudios Clásicos, 2011 (= Imágenes modernas del mundo antiguo).

Fernández URIel, P. - Rodríguez LóPez, I. (EDS.): Iconografía y sociedad en el Mediterráneo antiguo. Homenaje a la profesora Pilar González Serrano. Madrid, Signifer, 2011. (= Iconografía y sociedad).

Fuente, M.J. - MoRÁN, R. (EDS.): Raíces profundas. La violencia contra las mujeres (antigüedad y edad media). Madrid, Polifemo, 2011 (= Raíces profundas). 
García Blanco, M.J. et alii (eds.): 'Avtíðwoov. Homenaje a Juan José Moralejo. Santiago de Compostela, Universidad, 2011 (= Homenaje a Juan José Moralejo).

Jufresa, M. (ed.): Informació i comunicació a Grècia i Roma. Barcelona, Institut d'Estudis Catalans. Societat Catalana d'Estudis Clàssics, 2011 (= Informació i comunicació a Grècia i Roma).

Macías, C. - NúÑEz, S. (EDS.): Virtuti magistri honos. Studia Graecolatina A. Alberte septuagesimo anno dicata. Zaragoza, Pórtico, 2011 (= Virtuti magistri honos).

Martín Hernández, R. - Torallas Tovar, R. (eds.): Conversaciones con la muerte. Diálogos del hombre con el más allá desde la antigüedad hasta la edad media. 1 CD-ROM. Madrid, Consejo Superior de Investigaciones Científicas, 2011 (= Conversaciones con la muerte).

Navarro, M. - Perroni, M. (eds.): Los Evangelios. Narraciones e historia. Estella, Verbo Divino, 2011 (= Los evangelios. Narraciones e historia).

Pérez Jiménez, A. (ed.): Studia mystica, magica et mathematica ab amicis, sodalibus et discipulis Iosepho Ludovico Calvo oblata (= MHNH 11, 2011). Malaga, Universidad, 2011 (= Studia mystica, magica et mathematica).

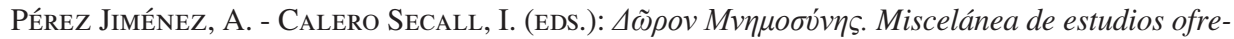

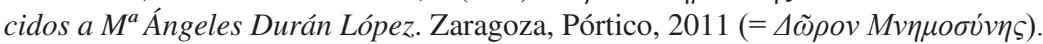

Pérez Jiménez, A. - Volpe Cacciatore, P. (eds.): Musa graeca tradita, musa graeca recepta. Traducciones de poetas griegos (siglos XV-XVII). Zaragoza, Pórtico, 2011 (Musa graeca tradita).

QuiJada SAgRedo, M. (ED.): Estudios sobre tragedia griega. Eurípides, el teatro griego de finales del s. V a.C. y su influencia posterior. Madrid, Ediciones Clásicas, 2011 (= Estudios sobre tragedia griega).

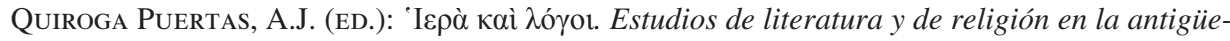

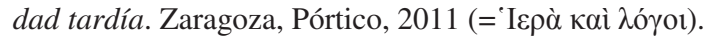

Ruiz Darasse, C. - Luján, E.R. (EDS.): Contacts linguistiques dans l'Occident méditerranéen antique. Madrid, Casa de Velázquez, 2011 (= Contacts linguistiques).

Sánchez Manzano, M.A. (ED.): Sabiduría simbólica y enigmática en la literatura grecolatina. Barcelona, Tecnos, 2011 (= Sabiduría simbólica y enigmática).

Santos Yanguas, J. - Díaz ARIÑo, B. (EDs.): Los griegos y el mar. Revisiones de historia antigua VI. Vitoria, Universidad del País Vasco, 2011 (=Los griegos y el mar).

Unceta Gómez, L. - López Gregoris, R. (COORds.): Ideas de mujer. Facetas de lo femenino en la Antigüedad. Alicante, Centro de Estudios sobre la Mujer de la Universidad de Alicante, 2011 (= Ideas de mujer).

Vicente Sánchez, A. - Beltrán Cebollada, J.A. (eds.): Grecia y Roma a escena. El teatro grecolatino: actualización y perspectivas. Madrid, Liceus, 2011 (= Grecia y Roma a escena).

\section{Autores antiguos. Ediciones, traducciones y ESTUdios}

\section{Acta Apostolorum Apocrypha}

Cerro Calderón, G. Del: El encratismo en los Hechos apócrifos de los Apóstoles», $4 \tilde{\omega} \rho o v$

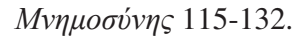

\section{Aelianus}

Giangrande, G.: «Sobre el texto y la lengua de Eliano», Veleia 28, 2011, 283-290.

\section{Aeschylus}

Adrados, F.R.: «Astrología y Magia en la Orestea de Esquilo», Studia mystica, magica et mathematica 205-211. 
Amaya Chávez, V.: «Sexo y muerte. Dos historias, una misma consecuencia», Thamyris 2, 2011, 67-80.

Angioni, M.C.: «L'Orestea nell'edizione di Robortello da Udine: alcuni casi di metafora e griphos», İtaca 27, 2011, 111-131.

Businarolo, L.: «L'Edizione eschilea del 1557: il contributo di Henri Estienne», İtaca 27, 2011, 133-153.

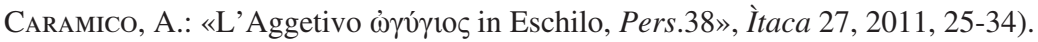

DAneloni, A.: «Eschilo e la tradizione eschilea nel laboratorio filologico di Angelo Poliziano», İtaca 27, 2011, 81-101.

Fernández-Galiano, M.: Esquilo. Madrid, Gredos, 2011.

JiméneZ Justicia, L.: «La caracterización animal de los personajes femeninos en la Orestiada», FI 22, 2011, 71-86.

PACE, G.: «La traduzione di Eschilo di Saint-Ravy: il caso dei Persiani, Musa graeca tradita 131-148.

Paco Serrano, D. de: «Las heroínas trágicas y la divinidad. Algunos ejemplos en el teatro de Esquilo y Eurípides», Eusebeia. Estudios de religión griega 219-254.

Pagliaroli, S.: «Per la Fortuna di Eschilo nell'umanesimo», İtaca 27, 2011, 57-80.

TAufer, M.: «Prometheus Vinctus di Jean Dorat: qualche stravaganza congetturale», İtaca 27, 2011, 103-109.

Tavonatti, P.: «Il Contributo di Francesco Porto alla filologia eschilea», İtaca 27, 2011, 155-164.

Tedeschi, C.: «La Distribuzione delle battute in Aesch.Ag.538-50», İtaca 27, 2011, 35-53.

— «Thomas Stanley ed i marginalia al testo di Eschilo», İtaca 27, 2011, 165-182.

\section{Anacreo}

Giangrande, G.: «Anacreon's sense of humour and the Greek language», Habis 42, 2011, 27-33.

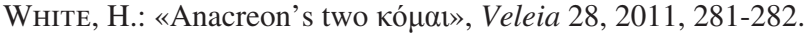

\section{Anacreontea}

Moya del Baño, F.: «Anacr.17, 28: $\pi \alpha \rho \varepsilon \lambda \theta$ óv, una ‘conjetura’ de Heynsius transmitida por Quevedo», Myrtia 26, 2011, 319-328.

PÉrez JimÉneZ, A.: «Sí, el Quevedo del Anacreón, helenista», Musa graeca tradita 103-130.

\section{Anthologia Graeca}

Antología Palatina. Libro XII. Poemas de amor efébico. Edición de R. González Delgado. Madrid, Akal, 2011.

El amor dorio. Epigramas eróticos griegos. Edición de G. GaLÁn Vioque. Madrid, Alianza Editorial, 2011.

\section{Antiochus Atheniensis}

Bautista Ruiz, H.: «Fuentes astrológicas de Los tesoros de Antíoco de Atenas», $\Delta \tilde{\omega} \rho o v$

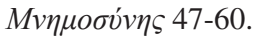

\section{Apollodorus}

ArJona Pérez, M.: «Egeo, Minos, Jacinto y Geresto: a propósito de un fragmento de la Biblioteca de [Pseudo]Apolodoro», 'Ilu 16, 2011, 7-31.

\section{Apollonius Rhodius}

Cancela Cilleruelo, A.: «Notas sobre la concordia en Apolonio de Rodas», CFCG 21, 2011, 231-246.

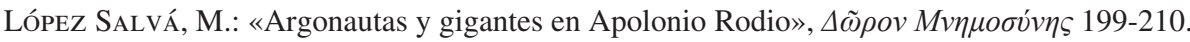




\section{Aratus}

Caldini Montanari, R.: «L' Orsa Minore e l'ora della notte in Arato (e in Cervantes)», Studia mystica, magica et mathematica 453-468.

\section{Aristophanes}

Gil Fernández, J.: «Aristophanes, Ecclesiazusae 923», CFCG 21, 2011, 153-155.

— «Notas a Aristófanes, Lisístrata», CFCG 21, 2011, 147-151.

Gil Fernández, L.: «Policar(e)idas (Aristófanes, Lisístrata, 1098, 1242)», Homenaje a Juan José Moralejo 339-347.

Macía Aparicio, L.M.: «Epítetos y expresiones de apariencia épica en las comedias de Aristófanes», Emerita 79, 2011, 229-250.

RAmón PAlerm, V.: «La comedia griega antigua: Aristófanes», Grecia y Roma a escena 97-130.

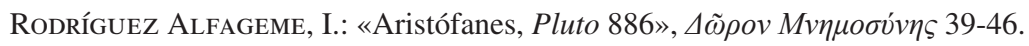

— «Inicios y finales de discurso en Aristófanes», Minerva 24, 2011, 113-135.

— «Nicias y su nieto en la comedia de Aristófanes», CFCG 21, 2011, 157-178.

\section{Aristóteles}

Aristóteles: Ética. Versión resumida y comentada por J.R. Ayllón. Madrid, Palabra Hoy, 2011.

— Ética y ciudadanía. Edición de J.R. Ramón Ayllón. Sevilla, Fundación Altair, 2011.

- Metafísica. Madrid, Globus Comunicación, 2011.

- Poética. Magna moralia. Introducciones, traducción y notas de T. Martínez Manzano y L. Rodríguez Duplá. Madrid, Gredos, 2011.

- Política. Estudio preliminar de S. Rus Rufino. Traducción del texto griego y notas de S. Rus Rufino y J.E. Meabe. Madrid, Tecnos, 2011.

- Protréptico, Metafísica. Física. Acerca del alma. Estudio introductorio por M. Candel. Traducción y notas de C. Megino Rodríguez y T. Calvo Martínez. Madrid, Gredos, 2011.

Becchi, F.: «Mimesi e catarsi trágica in Platone e Aristotele», Studia mystica, magica et mathematica 250-258.

Fuhrmann, M.: La teoría poética de la antigüedad. Aristóteles-Horacio - 'Longino'. Una introducción. Edición y traducción del alemán de A. Silván. Madrid, Dykinso, 2011.

Gallardo Paúls, E.: Anotaciones a la poética de Aristóteles: una aproximación desde el punto de vista de la teoría literaria. Valencia, Centro Francisco Tomás y Valiente - UNED AlziraValencia, 2011.

LLEDó, E.: El origen del diálogo y la ética. Una introducción al pensamiento de Platón y Aristóteles. Madrid, Gredos, 2011.

Lozano Díaz, V.: La noción aristotélica de filosofía primera. Madrid, Fundación Universitaria Española, 2011.

Meeusen, M.: «From reference to reverence: five quotations of Aristotle in Plutarch's Quaestiones naturales», Plutarco transmisor 347-364.

Muinelo Совo, J.C.: La invención del derecho en Aristóteles. Madrid, Dykinson, 2011.

PLÁCIDO, D.: «La concepción del trabajo libre en los socráticos y Aristóteles», Gerión 29(1), 2011, 99-106.

Solana Pujalte, J.: «Erratas y correcciones manuscritas de autor en la traducción latina de la Política de Aristóteles de Juan Ginés de Sepúlveda editada por Michel de Vascosan (París, 1548)», CFCL 31, 2011, 293-309.

Soto, L.G.: Teoría de la justicia e idea del derecho en Aristóteles. Madrid, Marcial Pons, 2011. 


\section{Artemidorus Ephesius}

CANFora, L.: El viaje de Artemidoro. Vida y aventuras de un gran explorador de la antigüedad. Madrid, La Esfera de los Libros, 2011.

\section{Bacchylides}

OвRISt, K.: «Deyanira, asesina de Heracles: un estudio de la coagulación mítica en Traquinias a partir del epinicio 5 y el ditirambo 16 de Baquílides», Veleia 28, 2011, 175-190.

\section{Biblia Graeca}

Aletheia, X.: «Localización de la comunidad de Lucas», EB 69(3), 2011, 289-300.

Byrskog, S.: «From Orality to Textuality: The Emergence of a New Form-Critical Paradigm», EB 69(1), 2011, 39-53.

Cerro Calderón, G. del: «Bilingüismo de Pablo de Tarso. Sus limitaciones», Virtuti magistri honos 75-87.

ChAPA, J.: «La materialidad de la Palabra: manuscritos que hablan», EB 69(1), 2011, 9-37.

Danove, P.: «The interpretation and translation of verbs of 'giving' in the New Testament», $F N$ 23(43), 2010, 109-127.

EsCAFFre, B.: «Marta», Los evangelios. Narraciones e historia 371-392.

FisCHER, I.: «Déjà-vu como prueba de la importancia salvífica. La importancia del género en la recepción de la Biblia hebrea en los escritos narrativos del Nuevo Testamento», Los evangelios. Narraciones e historia 85-110.

Foulkes, I.: Griego del Nuevo Testamento. 1 archivo de Internet. Barcelona, Clie, 2011.

Freyne, S.: «Entre imperio y sinagoga: explorando los papeles de mujeres en la Palestina romana temprana a través de la lente marcana», Los evangelios. Narraciones e historia 47-68.

García Santos, A.A.: Diccionario del Griego Bíblico. Setenta y Nuevo Testamento. Estella, Verbo Divino, 2011.

Hartenstein, J.: «Personajes masculinos y femeninos en el evangelio de Juan. Perspectivas de género», Los evangelios. Narraciones e historia 455-468.

HENDRIKs, W.: «Internal evidence of readings», EB 69(3), 2011, 301-322.

Himes, P.: «The use of the Aorist imperative in the Pastoral Epistles», FN 23(43), 2010, 73-92.

Hoеcк, A.: «2 Cor 3:17a Unlocks Paul's Dyadic Doxologies», EB 69(2), 2011, 217-228.

LEVINE, A.-J.: «El evangelio de Mateo: entre ruptura y continuidad», Los evangelios. Narraciones e historia 133-154.

LEVINSOHN, S.H.: «Aspect and prominence in the synoptic accounts of Jesus' Entry into Jerusalem», FN 23(43), 2010, 161-174.

Martínez Delgado, J. (ED.): El viaje lingüístico de la Biblia. Granada, Universidad, 2011.

Navarro Puerto, M.: «¿Discípulas en Marcos? Problematización de un concepto», Los evangelios. Narraciones e historia 155-180.

Norelli, E.: «Cómo nacieron los relatos sobre María y José en Mt 1-2 y Lc 1-2», Los evangelios. Narraciones e historia 329-348.

Osiek, C.: «Las ciencias bíblicas subsidiarias y la perspectiva feminista: una intersección fructífera», Los evangelios. Narraciones e historia 21-32.

PANG, F.G.H.: «Aspect, Aktionsart, and Abduction: future tense in the New Testament», FN 23(43), 2010, 129-159.

Pellegrini, S.: «Mujeres sin nombre en los evangelios canónicos», Los evangelios. Narraciones e historia 393-432.

Penna, P.: «Algunos modelos cristológicos desde la perspectiva de género en los evangelios canónicos», Los evangelios. Narraciones e historia 289-306. 
Pereira Delgado, Á.: «El poder del esclavo. La metáfora de la esclavitud en Flp 2,7 y 1 Co 9,19», EB 69(2), 2011, 185-216.

Perroni, M.: «Discípulas, pero no apóstoles: la obra de Lucas», Los evangelios. Narraciones e historia 181-222.

Petersen, S.: «María de Nazaret: historia de una transformación», Los evangelios. Narraciones e historia 349-370.

Pezzoli-Olgiati, D.: «Babilonia y Jerusalén como figuras femeninas en el Apocalipsis. Visiones, tradiciones e intermedialidad», Los evangelios. Narraciones e historia 253-276.

RAMSAY, R.B.: Griego y exégesis. 1 archivo de Internet. Barcelona, Clie, 2011.

Rius Camps, J. - Read-Heimerdinger, J.: «The variant readings of the Western text of the Acts of the Apostles (XXII) (Acts 14:28-15:41)», FN 23(43), 2010, 175-200.

Robertson, A.Th.: Comentario al texto griego del Nuevo Testamento. Traducción de S. Escuain Sanz. 1 Archivo de Internet. Barcelona, Clie, 2011.

Schottroff, L.: «"Mirad, estas son mis hermanas...” (Mc 3,34; Mt 12,49; Lc 8,21)», Los evangelios. Narraciones e historia 69-84.

SCHÜsSLer FiorenZA, E.: «La formación del canon del Nuevo Testamento y la marginalización de las mujeres», Los evangelios. Narraciones e historia 33-46.

Segura Munguia, S. - Torres Ripa, J.: Las plantas en la Biblia. Bilbao - Madrid, Universidad de Deusto - Consejo Superior de Investigaciones Científicas, 2011.

SEIM, T.K.: «Las mujeres y las negociaciones sobre el género en el evangelio de Juan», Los evangelios. Narraciones e historia 223-252.

Septién del Coso, J.A.: Griego bíblico al alcance de todos. 1 archivo de Internet. Barcelona, Clie, 2011.

Simian-Yofrem, H.: «La esclerosis de la Palabra: La Escritura «¿Qué está escrito? ¿Cómo lo lees? (Lucas 10,26)», EB 69(1), 2011, 55-77.

Smit Sibinga, J.: «From anointing to arrest: some observations on the composition of Mark 14:1-52», FN 23(43), 2010, 3-35.

Spottorno, M.V.: «Prefacio al Nuevo Testamento de la Biblia Políglota Complutense», Palabras bien dichas 111-126.

Tамаyo Acosta, J.J.: «Las fuentes religiosas cristianas: la Biblia y los Padres de la Iglesia», Raíces profundas 27-44.

TAschl-Erber, A.: «María de Magdala, ¿primera apóstol?», Los evangelios. Narraciones e historia $433-454$.

Thiessen, J.: «Zorndemonstration Gottes mit Heilsabsicht?: zur Problematik der Syntax und der Bedeutung von Römer 9, 22-23», FN 23(43), 2010, 37-72.

Tragán, P.-R.: «Las cartas de san Juan: la aportación de la exégesis de género», Los evangelios. Narraciones e historia 277-288.

Whiteley, I.M.: «Zechariah, reference and the structure of Revelation 6-8:1», FN 23(43), 2010, 93-108.

Witulski, Th.: «Die Datierung der Ap in die Zeit des Claudius- eine exegetische Möglichkeit?», EB 69(1), 2011, 79-91.

\section{Callimachus}

García López, Y.: «El Yambo II de Calímaco y el Crátilo de Platón o por qué los trágicos tienen voz de pez», Homenaje a Juan José Moralejo 293-304.

\section{Charito}

Laplace, M.: «Sobre la datación de la novela de Caritón: la figura de Demetrio el Cínico, lo contrario del verdadero filósofo», Emerita 79, 2011, 341-356. 


\section{Clemens Alexandrinus}

Calderón Dorda, E.: «Clemente de Alejandría y la doctrina astral», Studia mystica, magica et mathematica 438-452.

\section{Cono}

IвÁÑEz Chacón, A.: «Historia trágica de una tragedia histórica (Conón, Narr.50)», $\Delta \tilde{\omega} \rho o v$

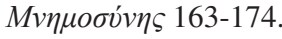

\section{Crates Mallotes}

Redondo Reyes, P.: «Homerica, astronomica: nota a Crates, frs. 25c y 5a Mette», Myrtia 26, 2011, 315-318.

\section{Ctesias}

Marasco, G.: «Fra storiografia e tragedia: Plutarco e Ctesia di Cnido», Plutarco transmisor 199-206.

\section{Demosthenes}

Demóstenes: Juicio contra una prostituta. Traducción de H. González. Prólogo de I. de los Ríos. Madrid, Errata Naturae, 2011.

Martín Velasco, M.J.: «Justicia y ley en el Contra Androción de Demóstenes», Homenaje a Juan José Moralejo 413-425.

SAncho Rocher, L.: «Riqueza, impiedad y üßpıs en el Contra Midias de Demóstenes», Emerita 79, 2011, 31-54.

\section{Dio Cassius}

D. Plácido SuÁrez: «La construcción de la imagen del imperio desde Grecia: la Historia romana de Dión Casio», Studia Historica. Historia antigua 29, 2011, 223-233.

\section{Dio Chrysostomus}

Giangrande, G.: «Dión Crisóstomo estropeado», Myrtia 26, 2011, 329-330.

\section{Diodorus Siculus}

Hernández de la Fuente, D.: Vidas de Pitágoras (según Porfirio, Jámblico, Diógenes Laercio, Diodoro de Sicilia, Focio de Constantinopla). Gerona, Atalanta, 2011.

MartíneZ-Pinna, J.: «Diodoro Sículo y los reyes de Roma», Gerión 29(1), 2011, 107-121.

\section{Diogenes Laertius}

Hernández de la Fuente, D.: Vidas de Pitágoras (según Porfirio, Jámblico, Diógenes Laercio, Diodoro de Sicilia, Focio de Constantinopla). Gerona, Atalanta, 2011.

\section{Empedocles}

Kahle, M.: «Empédocles y la pancagnividya», Convivencia e interacción 429-442

Megino, C.: «El origen del hombre según Empédocles», Mitos sobre el origen del hombre 263-296.

— «La transmigración en la poesía de Empédocles», Reencarnación 269-282.

Pereiro Pardo, a.: «Esfera», Homenaje a Juan José Moralejo 465-472.

\section{Epictetus}

Eрістето: Un manual de vida. Una nueva interpretación por Sharon Lebell. Traducción de B. Folch. Palma de Mallorca, José J. de Olañeta, 2011. 


\section{Epicurus}

CABAllero, R.: «Entre la necesidad del destino y la libertad del átomo: el clinamen de Epicuro y

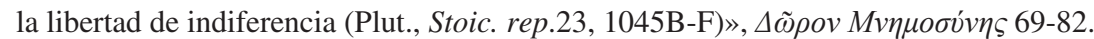

García Gual, C.: «Nietzsche y Epicuro», Estudios Nietzsche 11, 2011, 41-52.

PASCUAL, J.: «Epicuro y Atenas: la creación de una comunidad identitaria distinta de la Pólis», Studia Historica. Historia antigua 29, 2011, 39-63.

\section{Eunapius}

Quiroga Puertas, A.J.: «Una embajada ante Sapor II. Breves apuntes a Eunapio, VS 465-466»,

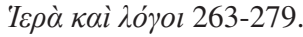

\section{Euripides}

Amendola, St.: «Due citazioni euripidee (Or. 420 e fr,. 979 Kn.) nel De sera numinis vindicta: riflessioni sulle prime traduzioni a stampa», Musa graeca tradita 149-166.

Brioso SÁnchez, M.: «Eurípides en Heliodoro: La carta de Fedra en Hipólito y el episodio de Cnemón en Etiópicas», Estudios sobre tragedia griega 233-256.

CALDERón Dorda, E.: «El sacrificio y su vocabulario en Eurípides», Eusebeia. Estudios de religión griega. 37-73.

Encinas Reguero, M.C.: «El relato de mensajero en el Orestes de Eurípides», Emerita 79, 2011, 131-154.

- «La estructura del Orestes de Eurípides y el enigmático relato del frigio», CFCG 21, 2011, 119-133.

EuRíPIDES: Hécuba. Introducción y traducción de J.L. Navarro. Madrid, Ediciones Clásicas, 2011.

Fernández Delgado, J.A.: «Un coro muy hesiódico de Eurípides (H.F. 734-480)», $\Delta \tilde{\omega} \rho o v$

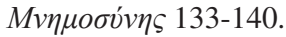

Giangrande, G.: «Sobre las ideas religiosas y políticas del último Eurípides», Eusebeia. Estudios de religión griega 161-167.

GuZMán, H.: «Eurípides-Racine-Bruckner: Tres enfoques de un mismo enfrentamiento», Tejiendo el mito 91-110.

LIAPIS, V.J.: «Notes on Rhesus», EC 15, 2011, 47-111.

Paco Serrano, D. de: «Las heroínas trágicas y la divinidad. Algunos ejemplos en el teatro de Esquilo y Eurípides», Eusebeia. Estudios de religión griega 219-254.

Pereira Rico, M.: «Parámetros sociolingüísticos en la elección de la primera persona en Hipólito de Eurípides», RSEL 40/1, 2010, 127-147.

QuiJada Sagredo, M.: «El Eurípides tardío y los límites de la tragedia», Estudios sobre tragedia griega 31-48.

— «Las seis versiones de la historia de Creusa en el Ión de Eurípides», Estudios sobre tragedia griega 49-72.

Romero Mariscal, L. - Campos Daroca, J.: «Mysterium Troianum? Dionysiac Mystic Patterns in Euripides' Trojan Woman», Studia mystica, magica et mathematica 399-405.

Rubiera Cancelas, C.: «Mujeres y hombres como víctimas de sacrificio en las tragedias de Eurípides. Lecturas», Arys 9, 2011, 99-118.

SAlvador, E.L.: «Mito, narrativa e audiència no monólogo de Jocasta (Eur.Phoen.1-87)», CFCG 21, 2011, 135-144.

TANGA, F.: «Una citazione euripidea nel Mulierum virtutes di Plutarco: osservazioni sulle traduzioni di età umanistica», Musa graeca tradita 167-180.

Volpe Cacciatore, P.: «Dall' Ippolito di Euripide alla Fedra di Marina Cvetaeva», $\Delta \tilde{\omega} \rho o v$

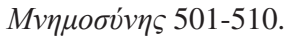

Zambujo Fialho, M.C.: «Novelesque elements in Euripides, Iphigenia in Tauris», Estudios sobre tragedia griega 73-82. 


\section{Eusebius Caesariensis}

Hubeñak, F.: «La construcción del mito de Constantino a partir de Eusebio de Cesarea», Polis 23, 2011, 61-87.

\section{Galenus}

LóPez PÉREz, M.: «Autoritarismo, persuasión y didáctica de la medicina en la obra de Galeno», Propaganda y persuasión 413-421.

\section{Glossaria}

Carracedo Fraga, J.: «Un glosario gramatical griego-latino en el códice Ripoll 74», Homenaje a Juan José Moralejo 121-131.

\section{Gregorius Nazianzenus}

Herrero de Jáuregui, M.: «Tradiciones e innovación en torno a $\tilde{\eta} \mu \alpha \rho$ en la poesía de Gregorio

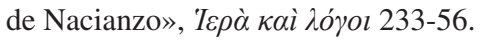

\section{Heliodorus}

Brioso Sánchez, M.: «Eurípides en Heliodoro: La carta de Fedra en Hipólito y el episodio de Cnemón en Etiópicas», Estudios sobre tragedia griega 233-256.

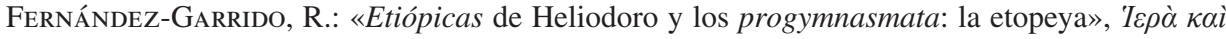
$\lambda o ́ \gamma o l$ 107-123.

IbáÑez Chacón, Á.: «La escena necromántica de las Etiópicas de Heliodoro», Studia mystica, magica et mathematica 319-334.

\section{Heraclitus}

Arana Marcos, J.R.: «Nietzsche: de Heráclito al mundo», Estudios Nietzsche 11, 2011, 13-26.

CRistóbal-Montes, Á.: Repensar a Heráclito. Madrid, Trotta, 2011.

\section{Herodas}

FERnÁndez Delgado, J.A.: Herodas' rhetoric of proverbs», Estudios sobre tragedia griega 219-232.

\section{Herodotus}

ÁlvareZ-Pedrosa NúÑEZ, J.A.: «El sueño de Jerjes (Heródoto 7, 12-18). Vestigios de un ritual de sustitución real», Convivencia e interacción 369-382.

ECHEverría Rey, F.: «Heródoto y la tragedia de Jerjes. Historia y narrativa trágica», Grecia ante los imperios 45-58.

GoÑ Zubieta, C.: Cuéntame una historia: un paseo por el mundo antiguo de la mano de Heródoto. Barcelona, Ariel, 2011.

Heròdot: Història. VIII. Text grec revisat, tradució i notes de J. Gestí. Barcelona, Alpha - Institut Cambó, 2011.

Heródoto: Historias, libro III. Texto revisado y traducido por F. Rodríguez Adrados. Madrid, Consejo Superior de Investigaciones Científicas, 2011.

Penadés Chust: «Heródoto y su posición ante los imperios de los siglos VI y V a.C.», Grecia ante los imperios 37-44.

\section{Hesiodus}

Brisson, L.: «El mito de Pandora», Mitos sobre el origen del hombre 129-152.

CARrasco Conde, A.: «Los orígenes del hombre en Hesíodo», Mitos sobre el origen del hombre 109-128. 
Fernández Delgado, J.A.: «La justicia del gavilán y sus audiencias (Op.2002-285)», Homenaje a Juan José Moralejo 257-269.

— «Plutarco comentarista de Hesíodo», Plutarco transmisor 23-36.

— «Astronomía, astrología y ornitomancia en Trabajos y Días», Studia mystica, magica et mathematica 469-483.

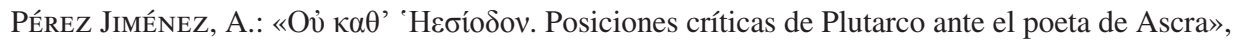

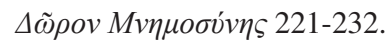

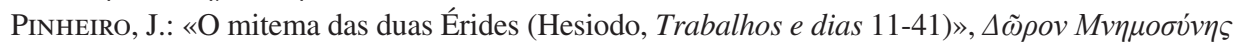
233-242.

Reig CALPE, M.: «La Veu de Tànatos i els fills de la Nit en el catàleg hesiòdic: algunes consideracions sobre les veus del més enllà», İtaca 27, 2011, 9-21.

\section{Himerius}

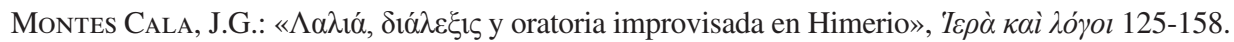

\section{Hippocrates et Corpus Hippocraticum}

ÁNGEL y EsPINós, J.: «El comentario de Francisco Vallés In libros Hippocratis de morbis popularibus: contexto histórico y antecedentes», Minerva 24, 2011, 195-208.

ÁNGEl EsPINós, J.: «En torno a la unidad del tratado hipocrático. De natura hominis a la luz de la estadística lingüística», $C F C G$ 21, 2011, 45-64.

Esteban Santos, A.: «Tipos de pasajes sobre enfermos individuales y su inserción en el todo en Epidemias II, IV y VI», CFCG 21, 2011, 179-192.

\section{Homerus}

Casadeusus Bordoy, F.: «Los mitos escatológicos en Platón: entre Homero y Orfeo», Eusebeia. Estudios de religión griega 97-119.

Fernández Delgado, J.A.: «Paráfrasis homéricas en papiros, tablillas y óstraka», EC 15, 2011, 3-45.

GARCíA LóPEZ, J.: «El vaticinio como elemento formal en la Telemaquia odiseica», Studia mystica, magica et mathematica 291-304.

Guzmán, H.: «La ópera King Priam de Tippett: de la épica homérica al drama musical», Minerva 24, 2011, 239-267.

Homero: El Cíclop: extret de «L'Odissea» d'Homer. Traducció de C. Riba. Il.lustracions de F. Amat. Sabadell, Alliance Française, 2011

- Ilíada. Prólogo, traducción y notas de Ó. Martínez García. Ilustraciones de J. Flaxman. Madrid, Alianza Editorial, 2011.

Míguez Barciela, A.: «Acerca del comienzo de la Odisea», Myrtia 26, 2011, 11-26.

PICón CASAs, J.: «El querer en la Ilíada», Helmantica 62(188), 2011, 251-274.

Redondo Reyes, P.: «Homerica, astronomica: nota a Crates, frs. 25c y 5a Mette», Myrtia 26, 2011, 315-318.

RiberA, J.M.: «Maragalliana: Nausica entre Nausícaas», Tejiendo el mito 229-246.

Santamaría Álvarez, M.A.: «Diálogos entre vivos y muertos en los poemas homéricos (Ilíada XXIII 65-107 y Odisea XI)», Conversaciones con la muerte 23-50.

SuÁreZ DE LA TORRE, E.: «Versos homéricos en los papiros mágicos griegos», Homenaje a Juan José Moralejo 527-543.

VAlverde Sánchez, M.: «Atenea y la intervención divina en la Odisea», Eusebeia. Estudios de religión griega 361-386. 


\section{Hymni Homerici}

Bernabé Pajares, A.: «Invocar a los dioses primigenios. El juramento de Hera (h.Ap.330-339) y el proemio del Canto de Kumarbi hitita, entre la magia y la literatura», Studia mystica, magica et mathematica 259-272.

\section{Hyperides}

MuÑoz FlóRez, J.: «El nuevo Hiperides In Diondam: introducción, traducción y notas», CFCG 21, 2011, 193-230.

\section{Iamblichus}

Hernández de la Fuente, D.: Vidas de Pitágoras (según Porfirio, Jámblico, Diógenes Laercio, Diodoro de Sicilia, Focio de Constantinopla). Gerona, Atalanta, 2011.

\section{Libanius}

Malosse, P.-L.: «La parole de Libanios: ‘faiblesse, discrédit et boue' ou `remède plus fort que

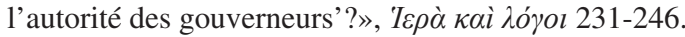

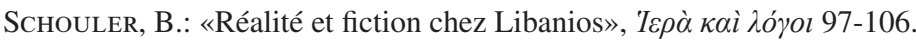

\section{Longinus rhetor}

Fuhrmann, M.: La teoría poética de la antigüedad. Aristóteles-Horacio - 'Longino'. Una introducción. Edición y traducción del alemán de A. Silván. Madrid, Dykinso, 2011.

\section{Lucianus}

Gómez Cardo, P.: «Paideia nutricia: las artes del saber y del comer en Luciano», CFCG 21, 2011, 247-260.

GonZÀLEZ Julià, Ll.: «Luciano ensaya la novela escénica: apariencia episódica y estructura unitaria de los Diálogos de los muertos», Emerita 79, 2011, 357-379.

IANNELlo, F.: «Mito, simbolismo e finzione nell'uso delle isole mobili e dei mostri marini nelle Verae Historiae. Note storico-religiose su alcuni paradossi lucianei», Cal.Ren.11, 2010, 89-106.

\section{Marcus Aurelius Antoninus}

McLynn, F.: Marco Aurelio. Guerrero, filósofo, emperador. Madrid, La Esfera de los Libros, 2011.

\section{Matro Pitaneus}

Amado Rodríguez, M.T.: «De serranos dermifloridos y platijas cartilaginosas. Hápax en la obra de Matrón de Pítane», Homenaje a Juan José Moralejo 21-33.

\section{Nonnus}

Jiménez Justicia, L.: «El mito de Procne y Filomela en las Dionisíacas de Nono de Panópolis»,

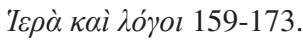

Miguélez Cavero, L.: «Espectáculos acuáticos en las Dionisíacas de Nono de Panópolis: ¿Refle-

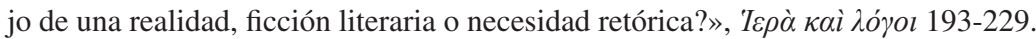

\section{Oribasius}

LóPez Pérez, M.: «Oribasio de Pérgamo y la pervivencia del paganismo a través de la medicina»,

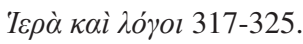




\section{Orphica}

BERnABÉ, A.: «El tíaso de los elegidos. El hades órfico como utopía», Conversaciones con la muerte 51-66.

\section{Paulus Alexandrinus}

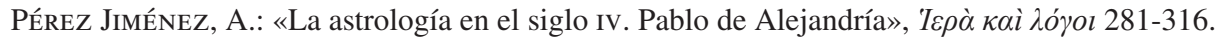

\section{Petosiris}

Candeias Sales, J. das: «Petosiris. Un activo constructor de la memoria egipcia del inicio del período ptolemaico», Studia Historica. Historia antigua 29, 2011, 17-38.

\section{Pherecydes Syrius}

Santamaría Álvarez, M.A.: «La transmigración del alma en Grecia de Ferecides de Siros a Píndaro (siglos VI-V a.C.)», Reencarnación 233-267.

\section{Philo Iudaeus}

Alesse, F.: «La `radice della mente' in Phil.Alex.Quod deter.84-85. Breve analisi di una metafora astrologica», Studia mystica, magica et mathematica 218-228.

LISI, F.L.: «El De opificio mundi de Filón de Alejandría», RPL 1, 2011, 1-16.

\section{Philostratus}

Vicente Sánchez, A.: Mal de amores en las Cartas Eróticas de Filóstrato. Teoría retórica y teoría epistolar. Zaragoza, Universidad, 2011.

\section{Philoxenus Cytherius lyricus}

Montes Cala, J.G.: «Los testimonios plutarqueos sobre Filóxeno de Citera», Plutarco transmisor 49-58.

\section{Pseudo Phocylides}

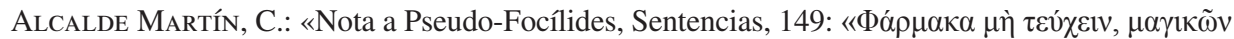

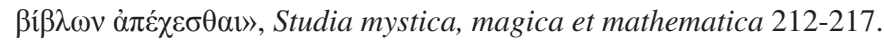

— «Quevedo, traductor de las Sentencias del Pseudo-Focílides», Musa graeca tradita 85-102.

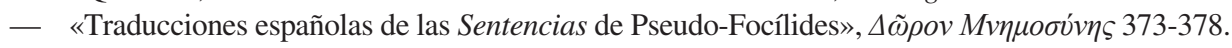

\section{Photius}

Hernández de la Fuente, D.: Vidas de Pitágoras (según Porfirio, Jámblico, Diógenes Laercio, Diodoro de Sicilia, Focio de Constantinopla). Gerona, Atalanta, 2011.

\section{Pindarus}

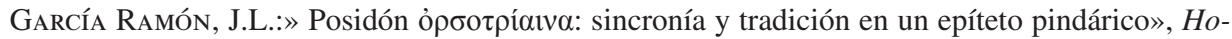
menaje a Juan José Moralejo 305-326.

González González, M.: «La Olímpica I de Pindaro en la versión de Fray Luis», Musa graeca tradita 35-52.

Santamaría Álvarez, M.A.: «La transmigración del alma en Grecia de Ferecides de Siros a Píndaro (siglos VI-v a.C.)», Reencarnación 233-267.

\section{Plato}

Becchi, F.: «Mimesi e catarsi trágica in Platone e Aristotele», Studia mystica, magica et mathematica 250-258. 
Bernabé, A.: Platón y el orfismo. Diálogos entre religión y filosofía. Madrid, Abada, 2011.

- «El mito de Protágoras sobre el origen del hombre», Mitos sobre el origen del hombre 297326.

Caballero Quemades, F.: Leyendo Fedón. Valencia, PUV, 2011.

Calero Secall, I.: «Disposiciones legales sobre sepulcros, capillas y entierros en las Leyes de Platón», Virtuti magistri honos 59-73.

- «Las Leyes de Platón: afinidades con las prescripciones de Gortina sobre el matrimonio»,

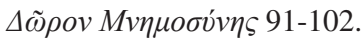

Casadeusus Bordoy, F.: «Los mitos escatológicos en Platón: entre Homero y Orfeo», Eusebeia. Estudios de religión griega $97-119$.

— «Platón y la noción de transmigración de las almas», Reencarnación 283-304.

Esteban, A.: «El mito del origen del hombre en el Banquete de Platón», Mitos sobre el origen del hombre 327-358.

García López, Y.: «El Yambo II de Calímaco y el Crátilo de Platón o por qué los trágicos tienen voz de pez», Homenaje a Juan José Moralejo 293-304.

HubeÑak, F.: «¿Fue Platón un patriota?», Helmantica 62(188), 2011, 295-330.

LLEDó, E.: El origen del diálogo y la ética. Una introducción al pensamiento de Platón y Aristóteles. Madrid, Gredos, 2011.

LuRI, G.: Introducción al Vocabulario de Platón. Sevilla, Fundación Ecoem, 2011.

Platón: El banquete. Fedro. Madrid, Globus Comunicación, 2011.

— Filebo. Introducción de J. Aguado Rebollo. Traducción y notas de E. Sánchez Millán. Edición Bilingüe. Madrid, Encuentro, 2011.

Müller, E.: «Diálogo crítico de Nietzsche con Platón», Estudios Nietzsche 11, 2011, 67-82.

Robinson, D. - Groves, J.: Platón, una guía gráfica. Todo lo que necesitas saber en 100 imágenes. Editado por R. Appignanesi. Traducción de P. Hermida Lazcano. Barcelona, Paidós, 2011.

SCHuré, E.: La atlántida. Evolución planetaria y origen del hombre. Madrid, Mestas, 2011.

Vernon, M.: Los podcasts de Platón. Guía de los antiguos para los modernos. Traducción de A. Pradera. Madrid, Alianza, 2011.

Waterfield, R.: La muerte de Sócrates. Toda la verdad. Traducción de J.L. Gil Aristu. Madrid, Gredos, 2011.

\section{Plutarchus}

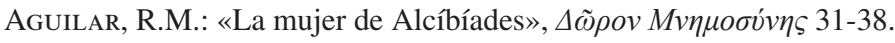

— «La transmigración en Plutarco», Reencarnación 305-326.

Ballesteros Pastor, L.: «El relato sobre Hipsicratea (Pomp. 32.7-8) y la imagen de Mitrídates en Plutarco», Plutarco transmisor 113-122.

BECK, M.: «Plutarch as a transmitter of space in the Lives», Plutarco transmisor 123-146.

BRENK, F.E.: «From wild beast to love divine. Plutarch between `pagan' and christian marriage», Plutarco transmisor 303-316.

Caballero, R.: «Entre la necesidad del destino y la libertad del átomo: el clinamen de Epicuro y

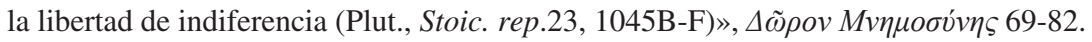

- «Quevedo traductor de Plutarco en la Doctrina estoica: las paradojas de los estoicos y las fantasías de los poetas», Musa graeca tradita 207-222.

Calderón Dorda, E.: «Plutarco transmisor de la elegía: Teognis y el corpus teognídeo», Plutarco transmisor 3-22.

CANdau Morón, J.M.: «Plutarco y la historiografía trágica», Plutarco transmisor 147-170.

CARAmico, A.: «O machinatrix lynce versipellior»: nota alla traduzione latina di Xylander di un frammento tragico (fr. trag. adesp.349 S.-K.), tràdito da Plutarco, De audiendis poetis 160D 8-9», Musa graeca tradita 181-192. 
Casanova, A.: «La hora del amor (Quaest. Conv. 3.6): Plutarco y la tradición (literaria y filosófica)», Plutarco transmisor 317-326.

Correia Martins, A.I.: «A recepção do motivo felicitas vera $\&$ falsa de Plutarco no tratado de filosofia moral de frei Luís de Granada», Plutarco transmisor 533-544.

Costa, V.: «La Vita di Teseo plutarchea e la tradizione dell' attidografia», Plutarco transmisor 171-186.

D’Ippolito, G.: «Il Dioniso di Plutarco», Plutarco transmisor 327-336.

Desideri, P.: «Roma: la buone ragioni di un impero», Plutarco transmisor 99-112.

FAu Ramos, M.T. - Jufresa MuÑOZ, M.: «El alejamiento de los mejores: el ostracismo en Plutarco», Plutarco transmisor 187-190.

Fernández Delgado, J.A.: «Plutarco comentarista de Hesíodo», Plutarco transmisor 23-36.

GAllé CeJudo, R.J.: «Plutarco y la transmisión de los fragmentos elegíacos de época helenística: algunas hipótesis sobre el Mulierum virtutes», Plutarco transmisor 37-48.

García LóPez, J.: «La actuación política en Plutarco (Mor.776b-827f)», Plutarco transmisor 471-480.

GonzÁlez Almenara, G.: «Las trabajadoras autónomas en Plutarco, ¿mujeres empresarias de la Grecia antigua?», Plutarco transmisor 481-494.

Hernández Gómez, M.: «La Carta séptima de Jenofonte y el Agesilao de Plutarco», Plutarco transmisor 191-198.

Hoof, L. VAN: «Entre transmisión y transformación: Plutarco sobre el cuidado de la salud», Plutarco transmisor 457-467.

Paco Serrano, D. de: «Problemas fisiológicos en el libro VI de Quaestiones convivales», Plutarco transmisor 337-346.

Marasco, G.: «Fra storiografia e tragedia: Plutarco e Ctesia di Cnido», Plutarco transmisor 199-206.

Martínez Hernández, M.: «Plutarco transmisor de las Islas de los Bienaventurados y su recepción en la historiografía canaria (ss. XVI-XIX)», Plutarco transmisor 545-568.

Martins de Jesús, C.A.: «Semíramis y Émpone. Dos historias de amor y desamor en el Amatorius de Plutarco», Plutarco transmisor 69-80.

Meeusen, M.: «From reference to reverence: five quotations of Aristotle in Plutarch's Quaestiones naturales», Plutarco transmisor 347-364.

Montes Cala, J.G.: «Los testimonios plutarqueos sobre Filóxeno de Citera», Plutarco transmisor 49-58.

Muccioli, F.: «Plutarco, il `buon uso' delle fonti epigrafiche e il decreto di Temistocle», Plutarco transmisor 207-222.

Muñoz Gallarte, I.: «Posidonio en Plutarco: acerca del nacimiento del alma del mundo», Plutarco transmisor 365-378.

Narro Sánchez, A.: «Los valores de la buena mujer en Plutarco a través del De Institutione feminae christianae de Luis Vives», Plutarco transmisor 569-584.

Nazaré Ferreira, L. de: «La transmisión de Simónides de Ceos por Plutarco», Plutarco transmisor 59-68.

NiEto IвÁñEZ, J.M.: «Plutarco transmisor de la polémica antioracular en la patrística griega», Plutarco transmisor 379-390.

Otтone, G.: «Plutarco trasmissore: ratio e prassi della citazione nella Vita di Agesilao», Plutarco transmisor 223-242.

Pérez Jiménez, A.: «De nuevo el Temístocles de Gracián / Enzinas de 1551. ¿Una traducción revisada?», Plutarco transmisor 585-598.

— «Ỏ̉ $\kappa \alpha \theta$ ' 'Hбíoбov. Posiciones críticas de Plutarco ante el poeta de Ascra», $\Delta \tilde{\omega} \rho o v$

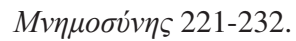

Pinheiro, J.: «A batalha de Maratona em Plutarco», Plutarco transmisor 243-251. 
Pino Campos, L.M.: «La presencia de Plutarco en la obra de José Ortega y Gasset», Plutarco transmisor 599-620.

Ramón Palerm, V.M.: «Plutarco y Juan de Pineda», Plutarco transmisor 621-632.

Redondo, J.: «Sobre la recepción de Plutarco en el primer cuarto de siglo XV: el Memorial del pecador Remut de Felip de Malla», Plutarco transmisor 633-644.

Ribeiro Ferreira, J.: «O respeito da lei e os valores da liberdade e da moderação no Cato Minor», Plutarco transmisor 252-266.

Rodrigues, A.R.: «O poder apotropaico do sangue (Quaest.Conv. 700e). Plutarco e a transmissão de uma prática agrícola ancestral», Plutarco transmisor 391-400.

Rodríguez Horrillo, M.A.: «Plutarco transmisor de Salustio: la Vida de Sertorio 10.5-7», Plutarco transmisor 267-276.

Roig LanZILlotTA, L.: «Plutarch of Chaeronea and the gnostic worldview: middle platonism and the Nag Hammadi library», Plutarco transmisor 401-418.

Romero, D.: «¿Qué es la mujer? Hechizo de perversidad», Plutarco transmisor 495-504.

Roskam, G.: «Two Quaestiones socraticae in Plutarch», Plutarco transmisor 419-432.

Ruiz Yamuza, E.: «Aproximación a las estrategias de mitigación en Plutarco: el uso de adversarios de modalidad», Plutarco transmisor 505-520.

SÁnCHEZ, A.V.: «La comunicación escrita en la antigüedad a través de la obra biográfica de Plutarco», Plutarco transmisor 521-529.

Santana Henríquez, G.: «¿Por qué resultaba odioso a los romanos el triunvirato? Las razones que nos trasmite Plutarco en las Vidas paralelas: Demetrio-Antonio», Plutarco transmisor 277-288.

SCANNAPIECO, R.: «Il morso della vipera, il sudore dell'anima. Il fr. plutarcheo 137 Sandbach»,

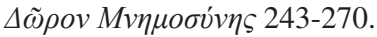

Stadter, P.A.: «Plutarch in Alexander Hamilton?s pay book», Plutarco transmisor 645-656.

Teodorsson, S.-T.: «Plutarch, a main source for the presocratics and the sophists», Plutarco transmisor 433-446.

Sтоскт, L. van der: «Some aspects of Plutarch's view of the physical world. Interpreting Causes of natural phenomena», Plutarco transmisor 447-456.

Valverde Sánchez, M.: «Eros e imaginación: a propósito de Plu., Mor.759b-c», Plutarco transmisor 81-96.

Vela Tejada, J.: «Plutarco transmisor de Jenofonte: alétheia y propaganda antiespartana en la Vida de Agesilao», Plutarco transmisor 289-299.

Vigorito; M.: «Sul De audiendis poetis di Plutarco: citazioni omeriche nelle traduzioni umanistiche», Musa graeca tradita 25-34.

Volpe Cacciatore, P.: «Citazioni poetiche nel De liberis educandis in alcune traduzioni umanistiche», Musa graeca tradita 193-206.

Voutsa, S.: «Constantinos Cavafis lee a Plutarco: historia, ironía y drama», Plutarco transmisor 657-674.

\section{Polybius}

Hoz, J. de: «Polibio, los edetanos y algunos problemas onomásticos», Homenaje a Juan José Moralejo 207-214.

Rosillo López, C.: «Los embajadores en las Historias de Polibio: entre la crónica y la búsqueda de apoyos», Grecia ante los imperios 329-334.

\section{Porphyrius Tyrius}

Hernández de la Fuente, D.: Vidas de Pitágoras (según Porfirio, Jámblico, Diógenes Laercio, Diodoro de Sicilia, Focio de Constantinopla). Gerona, Atalanta, 2011. 


\section{Posidonius Apamensis}

Muñoz Gallarte, I.: «Posidonio en Plutarco: acerca del nacimiento del alma del mundo», Plutarco transmisor 365-378.

\section{Proteuangelium Iacobi}

CAlderón Dorda, E.: «La suspensión de la naturaleza en el Protoevangelio de Santiago», $\Delta \tilde{\omega} \rho o v$

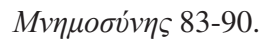

\section{Ptolemaeus}

Redondo Reyes, P.: «Los Harmonica de Ptolomeo en el Yalensis Beineckeus 208», FI 22, 2011, 169-190.

\section{Pythagoras}

Casadesús Bordoy, F.: «Pitágoras y el concepto de transmigración», Reencarnación 211-232.

Hernández de la Fuente, D.: Vidas de Pitágoras (según Porfirio, Jámblico, Diógenes Laercio, Diodoro de Sicilia, Focio de Constantinopla). Gerona, Atalanta, 2011.

\section{Quintus Smyrnaeus}

VAlverde SÁnchez, M.: «La magia del canto y de la música en Quinto de Esmirna», Studia mystica, magica et mathematica 410-422.

\section{Semonides}

GonZÁLEZ GonZÁLEZ, M.: «Semónides, la abeja y un matrimonio perfecto (CEG II 530)», $\Delta \tilde{\omega} \rho o v$

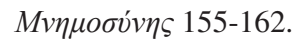

\section{Simonides}

Nazaré Ferreira, L. de: «La transmisión de Simónides de Ceos por Plutarco», Plutarco transmisor 59-68.

\section{Sophocles}

Barnés VÁzquez, A.: «Antígona, Hamlet, Odiseo y Don Quijote: una comparación», EH 33, 2011, 73-80.

Calvo Martínez, J.L.: «Los balbuceos del tirano. La aliteración en el agón Edipo-Tiresias (Edi-

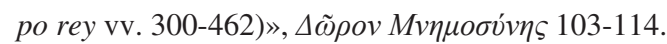

EnCinas Reguero, M.C.: «Exhibicionismo retórico y transformación narrativa en Edipo en Colono», Estudios sobre tragedia griega 105-130.

— «Los límites del dolor en el Filoctetes de Sófocles», Estudios sobre tragedia griega 83-104.

Herrero Ingelmo, M.C. - Montero Cartelle, E.: «El complejo de Antígona y el complejo de Ismene», Homenaje a Juan José Moralejo 349-354.

Martín GonZÁlez, E.: «El acertijo de la lira y la tortuga en Los rastreadores de Sófocles», Sabiduría simbólica y enigmática 317-326.

Navarrete Orcera, A.R.: «La iconografía de las Traquinias de Sófocles», Thamyris 2, 2011, 105-140. 
Martínez Hernández, M.: Sófocles. Erotismo, soledad, tradición. Madrid, Ediciones Clásicas, 2011.

OвRIST, K.: «Deyanira, asesina de Heracles: un estudio de la coagulación mítica en Traquinias a partir del epinicio 5 y el ditirambo 16 de Baquílides», Veleia 28, 2011, 175-190.

SAnfILIPPO, M.: «Antígona en la cultura italiana: de Elsa Morante a Mario Martone», Tejiendo el mito 247-258.

Sommerstein, A.H.: «Sophocles and the guilt of Oedipus», CFCG 21, 2011, 103-117.

Sófocles: Antígona. Traducción de M.P. Martín Yagüe. Madrid, Ediciones Clásicas, 2011.

Sófocles: Antígona. Traducción, introducción y notas de E. Delgado Ruiz. Prólogo de A. Martín Navarro. Sevilla, Fundación Altair, 2011.

Sófocles: Edipo rey. Edición y traducción de M.T. Beltrán Chabrera, M.T. Cases Fandos y M. García Ferrer (Grupo Galatea). Valencia, Tilde, 2011.

Sófocles: Edipo Rey. Valencia, L'Eliana, 2011.

Sófocles: Tragedias. Introducciones y versión rítmica de M. Fernández-Galiano. Madrid, Espasa Libros, 2011.

\section{Sophro}

Verdejo Manchado, J.: «La comicidad de lo obsceno en los fragmentos de Sofrón», Habis 42, 2011, 45-63.

\section{Sozomenus Salaminius}

Quiroga Puertas, A.J.: «Ghosts Stories in Sozomen's» Ecclesiastical History», Studia mystica, magica et mathematica 385-398.

\section{Strabo}

Cruz Andreotti, G. - Ciprés Torres, P.: «Más allá de la cartografía está la historia (a propósito de Estrabón e Iberia)», Los griegos y el mar 199-214.

Vilariño RodrígueZ, J.J.: «La Península Ibérica y los héroes griegos en la obra estraboniana», Studia Historica. Historia antigua 29, 2011, 183-196.

\section{Synesius Cyrenensis}

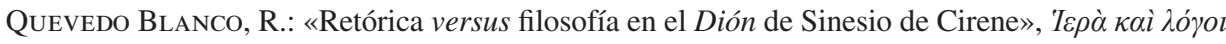
247-261.

\section{Tatianus}

Torres Prieto, J.: «La retórica como arma de propaganda y persuasión en la literatura polémica cristiana: el Discurso contra los griegos de Taciano», Propaganda y persuasión 269-278.

\section{Theocritus}

Martos Montiel, J.F.: «Autocensura en la traducción de los Idilios de Teócrito cum scholiis de Vicente Mariner», Musa graeca tradita 53-84.

Miguel Jover, J.L. de: «La educación de Heracles en el Idilio XXIV de Teócrito», Homenaje a Juan José Moralejo 215-228.

\section{Theognis}

CAlderón Dorda, E.: «Plutarco transmisor de la elegía: Teognis y el corpus teognídeo», Plutarco transmisor 3-22. 


\section{Thucydides}

Ledesma Pascal, A.: Realidad histórica y metáfora política en Tucídides. Tesis Doctoral. Madrid, Universidad Complutense de Madrid, 2011.

SAncho Rocher, L.: «Arché y democracia a la luz de Tucídides», Grecia ante los imperios 167-178

\section{Tragica Adespota}

CARAmico, A.: «O machinatrix lynce versipellior»: nota alla traduzione latina di Xylander di un frammento tragico (fr. trag. adesp.349 S.-K.), tràdito da Plutarco, De audiendis poetis 160D 8-9», Musa graeca tradita 181-192.

\section{Xenopho}

Gómez Castro, D.: «Trabajar para el enemigo. Los diez mil de Jenofonte a la luz de la investigación reciente», Grecia ante los imperios 197-206.

Hernández Gómez, M.: «La Carta séptima de Jenofonte y el Agesilao de Plutarco», Plutarco transmisor 191-198.

Vela Tejada, J.: «Plutarco transmisor de Jenofonte: alétheia y propaganda antiespartana en la Vida de Agesilao», Plutarco transmisor 289-299.

\section{Historia DE LA Literatura}

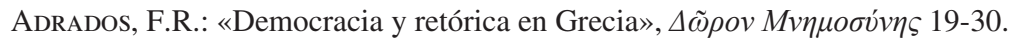

Beteta Martín, Y. - Fuente Pérez, M.J.: «La literatura como medio de difusión de la violencia contra las mujeres», Raíces profundas 221-252.

Brioso SÁNCHEZ, M.: «El personaje del ‘amigo’ novelesco entre la tragedia y la comedia: algunas precisiones», Habis 42, 2011, 83-101.

- «El rumor como motivo literario en la tragedia», Estudios sobre tragedia griega 131-200.

CResPo GüEMES, E.: «Viajando por obligación: las heroínas de la novela griega», Ideas de mujer 159-170.

Delaunois, M.: La originalidad del plan retórico en la elocuencia griega (siglos V y IV a.C). Traducción y edición de F.G. Hernández Muñoz. Madrid, Ediciones Clásicas, 2011.

Febres-Cordero, L.: Siete seminarios. Madrid, Verbum, 2011.

GAllé CEJudo, R.J.: «El exemplum mitológico en la elegía helenística: la función paradigmática

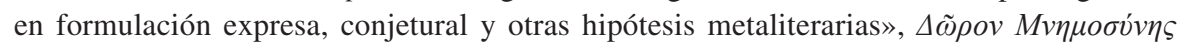
141-154.

GARcía LóPEZ, J.: «Música y mito en Grecia: los fragmentos musicales», Eusebeia. Estudios de religión griega $121-138$.

GonZÁlez GonzÁLez, M.: «Lejos de Atenas. Mujeres griegas y literatura», Ideas de mujer 107-130.

GuZmán Armario, F.J.: «Aqueménidas en la antigüedad tardía: las guerras médicas en las fuentes literarias del siglo IV», Grecia ante los imperios 361-370.

Hernández MuÑoz, F.G.: «Enigmas en la transmisión manuscrita de algunos autores griegos», Sabiduría simbólica y enigmática 339-352.

Hose, M.: «Der Tod der Tragödie. Über den Bedeutungsverlust einer literarischen Gattung am Ende des 5. Jhdts.», Estudios sobre tragedia griega 11-30.

Hualde Pascual, P.: «Las otras Ariadnas: mujeres abandonadas en la literatura clásica», Ideas de mujer 131-158.

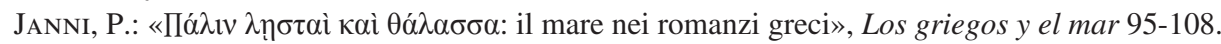


MÁrquez Ramos, E.: La música en la Antigua Grecia como transmisora de valores, repercusiones en la Educación Musical actual. Tesis Doctoral. Sevilla, Universidad, 2011.

Mata García, G.: «Historia de las alucinaciones en la Antigüedad», Gallaecia 30, 2011, 211-222.

Melero Bellido, A.: «Letras que cantan, hablan y danzan», Homenaje a Juan José Moralejo 427-439.

Molina Marín, A.I.: Geographica: ciencia del espacio y tradición narrativa de Homero a Cosmas Indicopleustes. Antigüedad y Cristianismo XXVII. Murcia, Universidad, 2011.

Paco Serrano, D: de: «Cassandra e le donne tragiche», Myrtia 26, 2011, 123-139.

Pajón Leyra, I.: Entre ciencia y maravilla. El género literario de la paradoxografía griega. Zaragoza, Universidad, 2011.

PéRez DíAz, E.: Las raíces de la lírica amorosa: estudio comparado de sus primeras manifestaciones (Súmer, Egipto, China, Grecia, Israel e India). Alcalá de Henares, Universidad, 2011.

Pérez JiméneZ, A.: «Homo verbosus erit. Condicionamientos astrológicos de la retórica antigua», Virtuti magistri honos 483-525.

PòrtUlas, J.: «La memòria enciclopèdica», Informació i comunicació a Grècia i Roma 51-80.

Prieto Domínguez, Ó.: De alieno nostrum: el centón profano en el mundo griego. Salamanca, Universidad, 2011.

QuiJada Sagredo, M.: «Tratamientos poéticos y narrativos del viaje y de la visión del mar en el teatro griego», Los griegos y el mar 109-126.

Reyes, A.: Libros y libreros en la antigüedad. Madrid, Fórcola, 2011.

Romilly, J. De: La tragedia griega. Madrid, Gredos, 2011.

Ruiz SolA, A.: Símbolos en el teatro griego», Sabiduría simbólica y enigmática 77-96.

SANCHO Rocher, L.: «Democracia y política en el teatro ateniense», Grecia y Roma a escena 17-50.

SANCHIS LlopIS, J.: «La comedia griega media y nueva», Grecia y Roma a escena 131-162.

SILVA, M.F.: «The foreigner living in Athens: a dramatic type character of the last quarter of the 5th century B.C.», Estudios sobre tragedia griega 201-218.

Torres Guerra, J.B.: Vtroqve sermone nostro. Bilingüismo social y literario en el Imperio de Roma / Social and literary bilingualism in the Roman empire. Barañáin, EUNSA, 2011.

Vela Tejada, J.: «Temas de ayer, de hoy y de siempre de la tragedia griega», Grecia y Roma a escena 51-96.

Vicente SÁncheZ, A.: «La puesta en escena en el teatro griego», Grecia y Roma a escena 163-195. Vinagre Lobo, M.A.: Los libros griegos de interpretación de sueños. Zaragoza, Pórtico, 2011.

\section{LingüÍSTICA GRIEGA. MÉtriCA}

Ángel EsPinós, J.: «En torno a la unidad del tratado hipocrático. De natura hominis a la luz de la estadística lingüística», $C F C G$ 21, 2011, 45-64.

BATs, M.: «Emmêlements de langues et de systèmes graphiques en Gaule méridionale (VIe-Ier siècle av. J.-C.)», Contacts linguistiques 197-226.

CAlderón Dorda, E.: «El hexámetro de las inscripciones funerarias griegas del siglo VI d.C.», Homenaje a Juan José Moralejo 111-119.

Caramico, A.: «L'Aggetivo ỏyúrı in Eschilo, Pers.38», İtaca 27, 2011, 25-34).

Cerro Linares, C. del: «El Golfo Pérsico en el I milenio a.C. Arqueología y toponimia aqueménida y griega en torno a la región de Maka-Magan», Convivencia e interacción 25-36.

CoRTÉs GabaudAn, F.: «Revisión de la historia de clavícula», Homenaje a Juan José Moralejo 133-139.

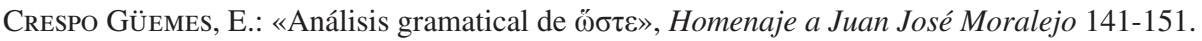

Danove, P.: «The interpretation and translation of verbs of 'giving' in the New Testament», $F N$ 23(43), 2010, 109-127. 
Destephen, S.: «La coexistence du grec et du latin en Illyricum (Ier-VIe siècle)», Contacts linguistiques 192-144.

DíAZ DE CERIO, M.: «T $\Omega$ ПO $\Delta \mathrm{E} \Sigma \mathrm{YMBAIN} \Omega$ y $\Pi \mathrm{O} \Delta \mathrm{A}$ BAIN $\Omega$ : sobre esquemas de complementación en griego antiguo», Homenaje a Juan José Moralejo 243-256.

Gallego, J.: «Atenas, entre el Krátos y la Arkhé. El lenguaje de la hegemonía y el agotamiento de la democracia», Grecia ante los imperios 155-166.

García RAmón, J.L.:» Posidón ỏpootpíalva: sincronía y tradición en un epíteto pindárico», Homenaje a Juan José Moralejo 305-326.

García Trabazo, J.V.: «Nuevas perspectivas en etimología griega a la luz del material anatolio», Homenaje a Juan José Moralejo 327-337.

Jiménez Delgado, J.M. - Martínez Vázquez, R.: «Verbos de movimiento virtual en griego antiguo», Emerita 79, 2011, 277-300.

JimÉnEz LóPEZ, M.D.: «Continuum de causatividad en griego antiguo: los verbos de influencia», CFCG 21, 2011, 85-101.

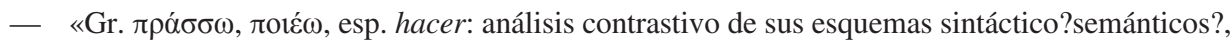
RSEL 40/2, 2010, 5-28.

LóPEZ FÉREZ, J.A.: «Brigos, briges, alóbriges y términos afines en la literatura griega hasta el siglo I a.C.», Homenaje a Juan José Moralejo 397-412.

MarTín de LuCAS, I.: «La partícula deíctica -1», CFCG 21, 2011, 65-83.

MARTín GonZÁLEz, E.: La prosa de las inscripciones griegas arcaicas. Tesis Doctoral. Valladolid, Universidad, 2011.

Martínez Vázquez, R. - Ruiz Yamuza, E.: «Una aproximación escalar al empleo de adverbio como adjunto y conjunto: oṽ $\omega \varsigma^{»}$, Habis 42, 2011, 317-338.

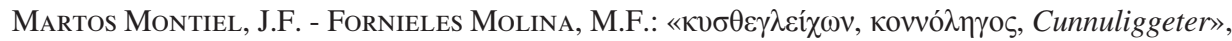

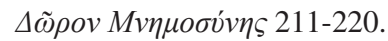

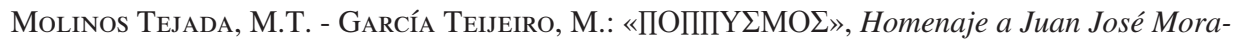
lejo 441-451.

Mullen, A.: «Reflets du multiculturalisme. La création et le développement du gallo-grec», Contacts linguistiques 227-240.

Nieto IzQuierdo, E.: «Notas sobre el dialecto de Cleonas y Nemea», Habis 42, 2011, 35-43.

PANG, F.G.H.: «Aspect, Aktionsart, and Abduction: future tense in the New Testament», FN 23(43), 2010, 129-159.

Pereira Rico, M.: «Parámetros sociolingüísticos en la elección de la primera persona en Hipólito de Eurípides», RSEL 40/1, 2010, 127-147.

Poccetti, P.: «Anthroponymes et toponymes issus d'ethniques et noms géographiques étrangers dans la Méditerranée archaïque», Contacts linguistiques 145-172.

Rodríguez Adrados, F.: «La colonización griega de Iberia. Mitos, héroes, topónimos», Homenaje a Juan José Moralejo 483-499.

Rodríguez Alfageme, I.: «Una etimología para $\mu \tilde{\theta} \theta$ os», Homenaje a Juan José Moralejo 501-508.

Torres Guerra, J.B.: Vtroqve sermone nostro. Bilingüismo social y literario en el Imperio de Roma / Social and literary bilingualism in the Roman empire. Barañáin, EUNSA, 2011.

Velaza Frías, J.: «Los contactos lingüísticos en la Hispania prerromana y romana. Cuestiones conceptuales y metodológicas», Contacts linguistiques 89-101.

VILla Polo, J. de la: «Directrices para el análisis sintáctico del griego antiguo», EClás.140, 2011, 105-132. 


\section{Micenología}

Bernabé Pajares, A.: «Las tablillas Fq 126 y 130 de Tebas», Homenaje a Juan José Moralejo 57-70.

Bernabé Pajares, A. - Serrano Laguna, I.: «Nuevos datos sobre la religión de la Tebas micénica: las tablillas de la Odos Pelopidou», Eusebeia. Estudios de religión griega 11-35.

\section{Epigrafía. Papirología. Numismática}

Beltrán Lloris, F. - Estarán Tolosa, M.J.: «Comunicación epigráfica e inscripciones bilingües en la Península Ibérica», Contacts linguistiques 9-26.

CAlderón Dorda, E.: «El hexámetro de las inscripciones funerarias griegas del siglo VI d.C.», Homenaje a Juan José Moralejo 111-119.

Calero Secall, I.: «Las Leyes de Platón: afinidades con las prescripciones de Gortina sobre el

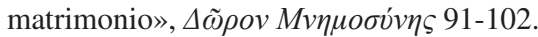

Casas Genover, J. - Hoz, M.P. de: «Un grafito del siglo VI a.C. en un vaso cerámico de Mas Gusó (Gerona)», Palaeohispanica 11, 2011, 231-248.

Fernández Delgado, J.A.: «Paráfrasis homéricas en papiros, tablillas y óstraka», EC 15, 2011, 3-45.

García Molinos, A.: «Los símbolos en los papiros griegos mágicos», Sabiduría simbólica y enigmática 135-144.

GiangRAnde, G.: «Una nueva arula griega hallada en Macedonia», Veleia 27, 2010, 379-380.

Gieseler Greenbaum, D. - Naether, F.: «Astrological Implications in the 'Lot Oracle' PGM 50», Studia mystica, magica et mathematica 484-505.

Hispania Epigraphica 17 (2008). Madrid, Universidad Complutense, 2011.

Martín Hernández, R.: «El fondo papirológico del padre Ubach de la Biblioteca de Montserrat», Palabras bien dichas 51-56.

— «El transporte de momias a través del Nilo. Los textos de las etiquetas de momia», Convivencia e interacción 543-554.

Mínguez Morales, J.A. - Díaz ARIÑo, B.: «Grafitos sobre cerámica -ibéricos, latinos, griegos y signos- procedentes del yacimiento romanorrepublicano de La Cabañeta (El Burgo de Ebro, Zaragoza)», AEA 84, 2011, 51-86.

Monaca, M.: «Una `Sibilla' nei Papiri Magici? Per una rilettura di PGM VI», Studia mystica, magica et mathematica 360-370.

Muccioli, F.: «Plutarco, il `buon uso’ delle fonti epigrafiche e il decreto di Temistocle», Plutarco transmisor 207-222.

Nodar Domínguez, A.: «Los papiros carbonizados de Butastis de la colección Palau Ribes: un estudio preliminar», Palabras bien dichas 89-99.

Ortega Monasterio, M.T.: «El instituto papirológico Roca-Puig y el CSIC: ¿Proyecto o realidad?», Palabras bien dichas 57-76.

Perea Yébenes, S.: «Un polífalo apotropaico inédito, con inscripción griega, contra la envidia», Studia mystica, magica et mathematica 59-82.

PiedRAFITA, C.: «Quatre breus inscripcions onomàstiques gregues d'Oxirrinc (campanyes 2007-2010)», SEBarc.9, 2011, 63-73.

REDONDO SÁNCHEZ, J.: «Sobre una inscripció hel.lenohebrea», SPhV 13, 2011, 223-230.

Santiago Álvarez, R.A. - Oller Guzmán, M.: «Relaciones con el exterior en el mundo griego antiguo: tempranos ejemplos de activa participación de la mujer», Minerva 24, 2011, 99-112.

Soler i Nicolau, A.: El fons epigràfic de la col.lecció Despuig d'escultura clàssica. Amb introducció a cura de M. Domínguez. Palma de Mallorca, Ajuntament de Palma, 2011. 
SuÁrez de la ToRre, E.: «Versos homéricos en los papiros mágicos griegos», Homenaje a Juan José Moralejo 527-543.

— «Magical Hermes: Remarks on the recipe of the 'Little Beggar' (PGM IV, 2373-2440)», Studia mystica, magica et mathematica 123-144.

Vives Cuesta, A.: «Tradición y sincretismo simbólicos en el culto isíaco: Proskynema en las inscripciones de Filé», Sabiduría simbólica y enigmática 117-134.

WorP, K.A.: «Female professional in the hellenistic world», Palabras bien dichas 77-87.

\section{Historia de LOS TEXTOS}

Bautista Ruiz, H.: «La escritura de la lengua griega desde sus primeros testimonios hasta la difusión del libro impreso», Thamyris 2, 2011, 81-103.

Redondo Reyes, P.: «Los Harmonica de Ptolomeo en el Yalensis Beineckeus 208», FI 22, 2011, 169-190.

Rius Camps, J. - Read-Heimerdinger, J.: «The variant readings of the Western text of the Acts of the Apostles (XXII) (Acts 14:28-15:41)», FN 23(43), 2010, 175-200.

Sanz Morales, M.: «Tradición indirecta y error de memoria en crítica textual griega: observaciones metodológicas», AEF 34, 2011, 237-252.

\section{Historia. Cultura. Sociedad}

AA.VV.: Los imperios y «el barbaro»: inmigrantes, profugos y marginados en el mundo antiguo. Studia historica. Historia antigua 28. Salamanca, Universidad, 2011.

Adrados, F.R.: Nueva historia de la democracia. De Solón a nuestros días. Barcelona, Ariel, 2011.

Alba López, A.: Teología política y polémica antiarriana. La influencia de las doctrinas cristianas en la ideología política del siglo IV. Salamanca, Universidad Pontificia de Salamanca, 2011.

Alfaro, C. - Brun, J.-P. - Borgard, P. - Pierobon Benoit, R.: Purpureae vestes, III: Textiles y tintes en la ciudad antigua / Tissus et teintures dans la cité antique / Tesuti e tenture a la città antica. Actas del III symposium internacional sobre textiles y tintes del Mediterráneo en el mundo antiguo (Nápoles, 13 al 15 de noviembre, 2008). Valencia, Universidad, 2011.

Alonso Troncoso, V.: «El espacio marítimo en los tratados internacionales de la Atenas clásica», Los griegos y el mar 237-252.

Assmann, J.: Historia y mito en el mundo antiguo. Los orígenes de la cultura de Egipto, Israel y Grecia. Madrid, Gredos, 2011.

Barceló, P.: Alejandro Magno. Madrid, Alianza, 2011.

— «Poder terrestre, poder marítimo: la politización del mar en la Grecia clásica y helenística», Los griegos y el mar 253-270.

Billows, R.A.: Maratón. El origen de la leyenda. Barcelona, Ariel, 2011.

Blanco Freijeiro, A.: Arte griego. $3^{\text {a }}$ edición revisada. Estudio preliminar de P. León. Madrid, CSIC, 2011.

BlázQuez Martínez, J.M. (ED.): Historia económica de España en la antigüedad. Madrid, Real Academia de la Historia, 2011 (= Historia económica de España en la antigüedad).

CEldrán GomáRIZ, P.: Quién fue quién en el mundo clásico. Vidas célebres y anécdotas de la antigüedad griega Madrid, Temas de Hoy, 2011.

Costa, A. - Palahí, L. - Vivó, D. (EDs.): Aquae sacrae. Agua y sacralidad en la Antigüedad. Actas de la reunión internacional (Girona, julio 12-13 de 2011). Girona, Institut de Recerca Històrica de la Universitat de Girona, 2011. 
Criado Boado, C.: «Las staseis de Atenas y la ideología de la ciudad no dividida», Homenaje a Juan José Moralejo 153-164.

Durán Vadell, M.: Los límites de Ares. Vencedores y vencidos en la Grecia antigua. Palma de Mallorca, Muntaner, 2011.

FERNÁNDEZ Nieto, F.J.: «Pesca, navegación y comercio en el mundo griego antiguo: su dimensión legal», Los griegos y el mar 271-311.

Fernández Uriel, P.: Dones del cielo. Abejo y miel en el Mediterráneo antiguo. Madrid, Universidad Nacional de Educación a Distancia, 2011.

Garrido GonZález, E.M.: «Panorámica de los estudios de género en la Antigüedad», Ideas de mujer 19-36.

Gómez, R.E.: Los clásicos, el esplendor griego, la gloria de Roma. Madrid, R.E. Gómez González, 2011.

Gómez Espelosín, F.J.: Historia de Grecia en la antigüedad. Madrid, Akal, 2011.

- Iberia e Hispania. Recursos para el estudio de la historia de España antigua. Alcalá de Henares, Universidad, 2011.

Iriarte, A.: Historiografía y mundo griego. Bilbao, Universidad del País Vasco, 2011.

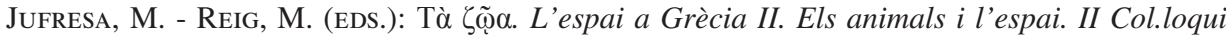
Internacional sobre la Concepció de l'Espai a Grècia (3-4 de Decembre 2009). Barcelona Tarragona, Institut d'Estudis Catalans - Institut Català d'Arqueologia Clàssica, 2011.

Lara Peinado, F.: Textos para la historia del Próximo Oriente antiguo. Madrid, Cátedra, 2011.

LEón, V.: El cadáver de Alejandro y otras historias de ciencia y superstición en la Antigüedad. Traducción de J. Estrella. Barcelona, Ariel, 2011.

López Quiroga, J.: «Gentes barbarae». Los bárbaros, entre el mito y la realidad. Antigüedad y Cristianismo 25 (2008). Murcia, Universidad, 2011.

Notario Pacheco, F.: «Perspectivas historiográficas de la alimentación en el mundo griego antiguo», Habis 42, 2011, 65-82.

Prados Torreira, L.: «Una aproximación a los estudios de género a través de la arqueología», Ideas de mujer 37-50.

Reig CAlPe, M.: «La imatge com a vehicle de transmissió de la informació a la polis grega», Informació i comunicació a Grècia i Roma 15-29.

Sainz De Bujanda, F.: Ordenamiento financiero de la antigua Grecia y el periodo helenístico. Prólogo de J. Sáinz Moreno. Madrid, Sáinz Moreno, 2011.

Salcines Cristal, J.V.: Historia del pensamiento económico: de Grecia al marginalismo. La Coruña, Escuela de Finanzas, 2011.

Sheppard, R.: Alejandro Magno. Guerras. Ejército. Sus batallas. Sus enemigos. Madrid, Libsa, 2011.

Vidal, J. - Antela, B. (eds.): La guerra en la antigüedad desde el presente. Zaragoza, Pórtico, 2011 (= La guerra en la antigüedad desde el presente.

Wood, E.M.: De ciudadanos a señores feudales. Historia social del pensamiento político de la antigüedad a la edad media. Barcelona, Paidós, 2011.

\section{Religión. Mitología}

Aguirre, M.: «Deucalión y Pirra», Mitos sobre el origen del hombre 241-262.

AlbriLE, E.: «Necromantica enteogena. Terapie e virtù psicoattive tra Grecia e Iran», Gerión 29(1), 2011, 83-97.

Alvar EzQuerra, J.: «La Alquimia del alimento: el sacrificio ritual», Arys 9, 2011, 21-32.

ANDRÉs PÉREZ, J.: «Tempus fugit. La iconografía del tiempo entre Grecia y Roma», Iconografía y sociedad 169-180. 


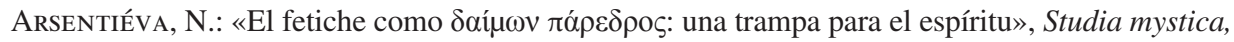
magica et mathematica 229-249.

Barón, J. - BurucúA, J.E. et alii: Los dioses cautivos. Madrid, Fundación Amigos Museo del Prado, 2011.

Bartolotti, A.: Mitología griega y romana. Dioses, héroes, semidioses y monstruos. Traducción de E. Coll. Barcelona, Swing, 2011.

Bermejo Barrera, J.C.: «Los hijos de la ola. Contribución al estudio de la mitología del mar en la Grecia antigua», Los griegos y el mar 15-36.

Bernabé Pajares, A.: Platón y el orfismo. Diálogos entre religión y filosofía. Madrid, Abada, 2011.

— «Invocar a los dioses primigenios. El juramento de Hera (h.Ap.330-339) y el proemio del Canto de Kumarbi hitita, entre la magia y la literatura», Studia mystica, magica et mathematica 259-272.

— «La transmigración entre los órficos», Reencarnación 179-210.

- Mendoza, J.: «Analogías y diferencias entre las doctrinas de la transmigración», Reencarnación 555-572.

Blázquez Martínez, J.M.: «Los orígenes del mito de Gerión», Convivencia e interacción 587-600.

BRISSON, L.: «El mito de Pandora», Mitos sobre el origen del hombre 129-152.

BURKert, W.: El origen salvaje. Ritos de sacrificio y mito entre los griegos. Prólogo de G.W. Most. Traducción del alemán de L.A. Bredlow. Barcelona, El Acantilado, 2011.

Buxton, R.: «En el principio. Los orígenes de los seres humanos en la mitología griega y en algunas otras mitologías», Mitos sobre el origen del hombre 33-58.

Caballero González, M.: El personaje mítico Atamante en las literaturas griega y latina. Tesis Doctoral. Madrid, Universidad Complutense de Madrid, 2011.

Cabrera, A. - Turell, L.: «Tejidos de la Antigüedad tardía en Egipto: representaciones de temas báquicos», Iconografía y sociedad 329-338.

Campos Méndez, I.: «Los griegos y la religión del imperio persa aqueménida: el dios Mithra», Grecia ante los imperios 207-216.

CAmps Gaset, M.: «Las Haloas áticas: rituales patrios, diversión femenina», Eusebeia. Estudios de religión griega 75-95.

Cardona Castro, F.L.: Mitología griega. Barcelona, Brontes, 2011.

Casadesús Bordoy, F.: «Pitágoras y el concepto de transmigración», Reencarnación 211-232.

CitAti, P.: La luz de la noche. Los grandes mitos en la historia del mundo. Traducción de J. Díaz de Atauri. Barcelona, El Acantilado, 2011.

Escobedo, J.C.: Enciclopedia de la mitología. Barcelona, De Vecchi, 2011.

Esteban Santos, A.: Dioses. I, Preolímpicos (personajes de la Teogonía). Madrid, Dhyana Arte, 2011.

- Mitos de Grecia. Los cuentos más fantásticos. I. El remoto origen de los dioses. Madrid, Dhyana Arte, 2011.

— «Grecia antigua: en el mito como en la realidad», Iconografía y sociedad 125-138.

Fernández Delgado, J.A.: «La otra cara de Delfos», Sabiduría simbólica y enigmática 257-282.

FERNÁNDEZ NiETo, F.J.: «Un término sospechoso: la piedra amuleto zamílampis / zmilanthis», Studia mystica, magica et mathematica 285-290.

Fontenrose, J.: Python. Estudio del mito délfico y sus orígenes. Traducción de M. Tabuyo y A. López. Madrid, Sexto Piso, 2011.

García-Gasco, R.: «La estirpe de la tierra: fundadores y primeros pobladores», Mitos sobre el origen del hombre 215-240.

García López, J.: «Música y mito en Grecia: los fragmentos musicales», Eusebeia. Estudios de religión griega 121-138. 
García Molinos, A.: «Los símbolos en los papiros griegos mágicos», Sabiduría simbólica y enigmática 135-144.

García Soler, M.J.: «Entre lo sagrado y lo profano: la figura del mageiros en la antigua Grecia», Arys 9, 2011, 85-98.

García TeiJeiro, M.: Las alegorías del mar en la mitología clásica», Los griegos y el mar 77-94.

— «Legislación imperial contra magia y adivinación en el siglo IV», Eusebeia. Estudios de religión griega 139-160.

Gieseler Greenbaum, D. - Naether, F.: «Astrological Implications in the 'Lot Oracle’ PGM 50», Studia mystica, magica et mathematica 484-505.

González González, M.: «El Polytheismo elucidado (1753) de Don Blas Hipólito García y la Genealogía de los dioses paganos de Boccaccio», Virtuti magistri honos 109-124.

González VAquerizo, H.: «Duplicidad de una mujer griega. Helena como fantasma de la duplicidad femenina en el mundo griego», Ideas de mujer 93-106.

GonZÁlez Zymla, H.: «Ares en Grecia: iconografía del dios de la guerra», Iconografía y sociedad 181-190.

Gordillo Hervás, R.: «La organización adrianea de los certámenes panhelénicos», Grecia ante los imperios 335-344.

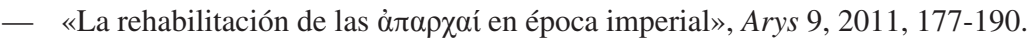

Gordon, R.: «Signa nova et inaudita: The theory and practice of invented signs (charaktêres) in Graeco-Egyptian magical texts», Studia mystica, magica et mathematica 15-44.

Hansen, W.F.: Los Mitos clásicos. Una guía del mundo mítico de Grecia y Roma. Traducción castellana de E. del Valle. Barcelona, Crítica, 2011.

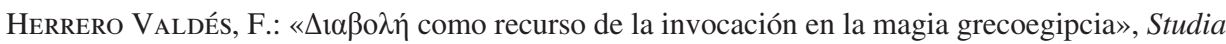
mystica, magica et mathematica 305-318.

Hualde Pascual, P.: «Las otras Ariadnas: mujeres abandonadas en la literatura clásica», Ideas de mujer 131-158.

HüBNER, W.: «Die doppelte Zodiakalfigur im Stundenbuch des Duc de Berry», Studia mystica, magica et mathematica 161-180.

Jiménez SAn Cristóbal, A.I.: «El más allá en inscripciones dionisíacas», Conversaciones con la muerte 67-94.

— «Fiestas dionisíacas», Eusebeia. Estudios de religión griega 169-196.

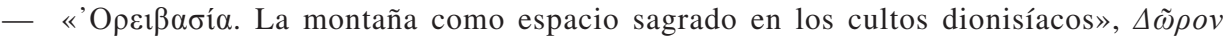
Мvпноби́vทৎ 175-188.

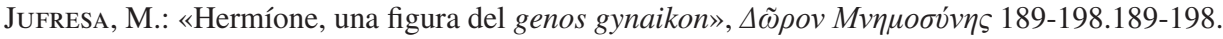

LENDON, J.E.: Soldados y fantasmas. Mito y tradición en la Antigüedad clásica. Traducción de D. Aldea Rossell e I. Muzás Calpe. Barcelona, Ariel, 2011.

Lesage Gárriga, L. - Navarrete Orcera, A.: Crónicas mitológicas. Un año de Cultura Clásica. Madrid, Cultivalibros, 2011.

López Jimeno, A.: «Textos de magia profesional de Chipre», Studia mystica, magica et mathematica 335-350.

López SALvÁ, M.: «Los orígenes del hombre en el Próximo Oriente (Mesopotamia y la Biblia)», Mitos sobre el origen del hombre 59-108.

López Kindler, A.: Zeus vs. Deus. La resistencia de la cultura pagana al cristianismo. Madrid, Rialp, 2011.

LóPEZ-Ruiz, C.: «Mot, Hades y la muerte personificada en el Levante y Grecia», Conversaciones con la muerte 9-22.

Macías, S. - Porres, S.: «El origen del hombre en el mito central del orfismo», Mitos sobre el origen del hombre 153-186. 
Lozano Guillén, C.: «Las musas y los órganos productores de los sonidos», Virtuti magistri honos 141-159.

Martín, R. - Álvarez-Pedrosa, J.A.: «Creencias escatológicas de los pueblos tracios», Reencarnación 163-178.

Martín Hernández, R.: «Invocaciones a los muertos en los textos griegos mágicos», Conversaciones con la muerte 95-116.

Mastrocinque, A.: «Laminetta magica in argento raffigurante il gallo anguipede e Persefone», Studia mystica, magica et mathematica 351-359.

Nieto IвÁñez, J.M.: «Enigma de Apolo, sabiduría cristiana», Sabiduría simbólica y enigmática 283-302.

Notario Pacheco, F.: «Manjares de cuna y lecho: los banquetes sacrificiales natalicios y nupciales en la democracia ateniense del siglo IV a.C.», Arys 9, 2011, 67-83.

Paco Serrano, D. de: «Cassandra e le donne tragiche», Myrtia 26, 2011, 123-139.

Pellizer, E.: «La nozione di daímon nella Grecia arcaica (fino a Platone escluso)», Eusebeia. Estudios de religión griega 255-272.

Perea Yébenes, S.: «Amuletos griegos, una mitología extravagante, una fe alternativa: el ejemplo de Tántalo El bebedor de sangre», Eusebeia. Estudios de religión griega 273-322.

Perea Yébenes, S. - SaURA, D.: «El lenguaje coactivo en la magia grecorromana y en los exorcismos», Propaganda y persuasión 367-399.

PÉrez JimÉnEZ, A.: «La constelación greco-romana del altar y sus implicaciones astrológicas en la religión», Eusebeia. Estudios de religión griega 323-360.

Piquemal, M.: Las mejores fábulas mitológicas. Ilustraciones de K. Amate. Traducción de D. Montsech. Barcelona, Oniro, 2011.

Prieto Domínguez, O.: «Eco, símbolo literario y signo metaliterario en la poesía griega postclásica», Sabiduría simbólica y enigmática 145-158.

Reig CALPE, M.: «La Veu de Tànatos i els fills de la Nit en el catàleg hesiòdic: algunes consideracions sobre les veus del més enllà», İtaca 27, 2011, 9-21.

Rives, J.B.: «Religious Choice and Religious Change in Classical and Late Antiquity: Models and Questions», Arys 9, 2011, 265-280.

Rodrigues, A.R.: «O poder apotropaico do sangue (Quaest.Conv. 700e). Plutarco e a transmissão de uma prática agrícola ancestral», Plutarco transmisor 391-400.

Rodríguez Blanco, M.E.: «Las mujeres monstruo y monstruos de mujer en la mitología griega», Ideas de mujer 65-92.

Rodríguez Peinado, L.: «Representaciones mitológicas en los tejidos del valle del Nilo», Iconografía y sociedad 339-347.

Rodríguez PÉREZ, D.: «La serpiente como símbolo en el mundo griego: escenas del `más acá’», Sabiduría simbólica y enigmática 97-116.

— «Mujeres, esclavos y niños en el culto a Zeus Miliquio: análisis iconográfico de los relieves votivos», Iconografía y sociedad 157-167.

Santamaría Álvarez, M.A.: «La transmigración del alma en Grecia de Ferecides de Siros a Píndaro (siglos VI-V a.C.)», Reencarnación 233-267.

SANTini, C.: «La reflexión sobre las religiones mistéricas en la filosofía de Nietzsche», Estudios Nietzsche 11, 2011, 83-98.

Scalera McClintock, G.: «El origen titánico de la raza humana. Modelos y desarrollo de un mito filosófico», Mitos sobre el origen del hombre 187-214.

Schmitt Pantel, P.: Dioses y diosas de la Grecia antigua explicados a todo el mundo. Traducción de R. Rius Gatell. Barcelona, Paidós, 2011.

SCHURÉ, E.: La atlántida. Evolución planetaria y origen del hombre. Madrid, Mestas, 2011.

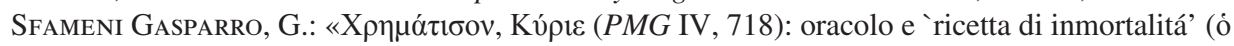
$\dot{\alpha} \pi \alpha \theta \alpha v \alpha \tau \iota \sigma \mu o ́ \varsigma)$, tra religione filosofica, mistero e magia», Studia mystica, magica et mathematica 83-122. 
Solé García, C.: «Significado de los hermai en la antigua Grecia», Iconografía y sociedad 139-146. SuÁrez de LA ToRre, E.: «Magical Hermes: Remarks on the recipe of the 'Little Beggar' (PGM IV, 2373-2440)», Studia mystica, magica et mathematica 123-144.

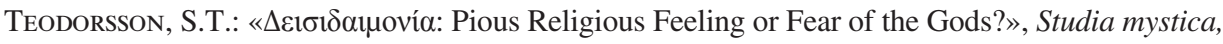
magica et mathematica 557-562.

Torallas Tovar, S.: «Textos y contextos funerarios en el Egipto grecorromano: el caso de las etiquetas de momia», Conversaciones con la muerte 117-128.

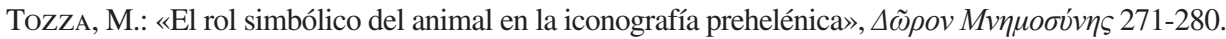

VAldÉs Guía, M.: «Banquetes funerarios y Eupátridas: el ritual de Opferrinnen en Atenas arcaica», Arys 9, 2011, 49-65.

Valtierra Lacalle, A.: La palmera en el imaginario griego de la antigüedad. Iconografía en Delos (VI-IV a.c.). Tesis doctoral. Madrid, Universidad Autónoma de Madrid, 2011.

Verdía BARBARÁ, B.: La antropología victoriana y el estudio de la religión griega. Tesis Doctoral. Santiago de Compostela, Universidad, 2011.

Vives Cuesta, A.: «Tradición y sincretismo simbólicos en el culto isíaco: Proskynema en las inscripciones de Filé», Sabiduría simbólica y enigmática 117-134.

WulfF Alonso, F.: «Indra en femenino. Notas entre la India y Grecia a propósito del Mahâbhâra-

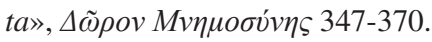

\section{CRistianismo}

Albarrán Martínez, M.J.: Ascetismo y monasterios femeninos en el Egipto tardoantiguo. Estudio de papiros y ostraca griegos y coptos. Barcelona, Publicaciones de la Abadía de Montserrat, 2011.

— «El monacato y el más allá en el Egipto tardoantiguo», Conversaciones con la muerte 129146.

ARCARI, L.: «¿Qué mesías para las mujeres? Mesianismos judíos y cristologías protocristianas desde la perspectiva de género: posible itinerario histórico-religioso», Los evangelios. Narraciones e historia $111-132$.

Castillo Maldonado, P.: «El viaje de la reliquia. La contribución de los peregrinos a la genera-

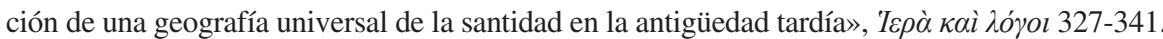

Corley, K.E.: Maranatha. Ritos funerarios de las mujeres y los orígenes del cristianismo. Estella, Verbo Divino, 2011.

Destro, A. - Pesce, M.: «Dentro y fuera de las casas. Transformaciones en el papel de las mujeres desde el movimiento de Jesús hasta las primeras iglesias», Los evangelios. Narraciones e historia 307-328.

Fernández Galiano, D.: Los monasterios paganos. La huida de la ciudad en el mundo antiguo. Córdoba, El Almendro, 2011.

FRANCHI, R.: «Materia, libero arbitrio e origine del male nell' apologetica cristiana dei primi secoli», Helmantica 62(188), 2011, 369-390.

GuZmán Armario, F.J.: «Cristianismo y paganismo: la lucha política en Roma y Constantinopla

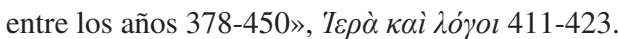

LóPez Kindler, A.: Zeus vs. Deus. La resistencia de la cultura pagana al cristianismo. Madrid, Rialp, 2011.

LóPez SAlvÁ, M. - Herrero DE JÁUREGUi, M.: «La transmigración en el cristianismo primitivo», Reencarnación 385-415.

Nieto IвÁÑEZ, J.M.: «Aspectos de la religiosidad griega tardía en los autores patrísticos», Eusebeia. Estudios de religión griega 197-217. 
Santos Yanguas, N.: «Conflicto entre estado romano y cristianismo durante el primer siglo», Helmantica 62(188), 2011, 331-353.

Tamayo Acosta, J.J.: «Las fuentes religiosas cristianas: la Biblia y los Padres de la Iglesia», Raíces profundas 27-44.

\section{Filosofía. Ciencia}

ARNAUD, P.: «La mer dans la construction grecque de l'image du monde», Los griegos y el mar 129-154.

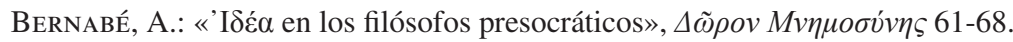

BiAnChETTI, S.: «I greci e il «mare esterno»: dalle esplorazioni delle aree estreme alla rappresentazione «scientifica» dell' ecumene», Los griegos y el mar 155-162.

Bordoy, A.: «La transmigración del alma en el neoplatonismo pagano», Reencarnación 327-350.

Colli, G.: Filósofos sobrehumanos. Edición de E. Colli. Traducción del italiano de M. Morey. Madrid, Siruela, 2011.

Cornford, F.M.: Antes y después de Sócrates. Traducción de A. Pérez Ramos. Barcelona, Ariel, 2011.

Dumont, J.-P.: La filosofía antigua. Traducción de S. Amezcua. Barcelona, Davinci Continental, 2011.

Durán López, M.Á.: Los dioses en crisis. Actitud de los sofistas ante la tendencia religiosa del hombre. Madrid, Ediciones Clásicas, 2011.

González, V. - Gustavo, Á.: Ciencia y técnica en el antiguo mundo griego. Madrid, Cultiva Libros, 2011

GonZÁlez Marín, C.: «De la risa al embarazo. Los filósofos y la violencia contra las mujeres», Raíces profundas 173-190.

Lozano Velilla, A.: «Los carios y el mar. ¿Leyenda o realidad histórica?», Los griegos y el mar 217-236.

MARCotte, D.: «Regards sur l'Atlantique au tournant de notre ère», Los griegos y el mar 173-184.

Martínez García, J.A.: La virtud en el personalismo francés. Un estudio desde sus fuentes griegas y latinas. Tesis Doctoral. Murcia, Universidad, 2011.

MAs ToRres, S.: Sabios y necios. Una aproximación a la filosofía helenística. Madrid, Alianza, 2011.

Molina Marín, A.I.: Geographica: ciencia del espacio y tradición narrativa de Homero a Cosmas Indicopleustes. Antigüedad y Cristianismo XXVII. Murcia, Universidad, 2011.

PÉREZ JimÉnez, A.: «La talasocracia de las estrellas en Grecia: vivir y morir en el mar mirando al cielo», Los griegos y el mar 37-66.

Prieto Esteban, M.J.: Plantas y árboles en el mundo clásico. Prólogo de J. de la Villa Polo. Madrid, Áurea Clásicos, 2011.

Prontera, F.: «Il Mediterraneo nella cartografia antica», Los griegos y el mar 185-198.

Roig Lanzillotta, L.: «Plutarch of Chaeronea and the gnostic worldview: middle platonism and the Nag Hammadi library», Plutarco transmisor 401-418.

Román Alcalá, R.: Pirrón de Elis. Un pingüino y un rinoceronte en el reino de las maravillas. Córdoba, Universidad, 2011.

Sambursky, S.: El mundo físico de los griegos. Taducción de M.J. José Pascual Pueyo. Madrid, Alianza, 2011.

Saviesa grega arcaica. A cura de J. Pòrtulas i S. Grau. Barcelona, Adesiara, 2011.

Sтоскт, L. van der: «Some aspects of Plutarch's view of the physical world. Interpreting Causes of natural phenomena», Plutarco transmisor 447-456. 
Su, P.-Y.: El concepto de amistad. El pensamiento de autores clásicos y cristianos. Barañáin, EUNSA, 2011.

Teodorsson, S.-T.: «Plutarch, a main source for the presocratics and the sophists», Plutarco transmisor 433-446.

Teruel, P.J.: Filosofía y ciencia en Hipatia. Madrid, Gredos, 2011.

Vernant, J.P.: Los orígenes del pensamiento griego. Traducción de M. Ayerra Redin. Barcelona, Paidós, 2011.

Waterfield, R.: La muerte de Sócrates. Toda la verdad. Traducción de J.L. Gil Aristu. Madrid, Gredos, 2011.

Williams, B.: Vergüenza y necesidad. Recuperación de algunos conceptos morales de la Grecia antigua. Madrid, Machado Grupo de Distribución, 2011.

Zaragoza Gras, J.: «La transmissió de la medicina grega», Informació i comunicació a Grècia i Roma 31-50.

\section{Pervivencia. Humanismo. Historia de la filología}

Adrados, F.R.: «La tradición clásica en la poesía de Luis Alberto de Cuenca», Emerita 79, 2011, 195-198.

Alcalde Martín, C.: «Quevedo, traductor de las Sentencias del Pseudo-Focílides», Musa graeca tradita 85-102.

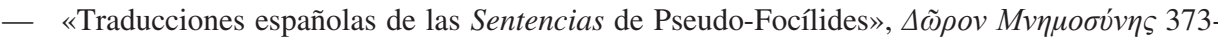
378.

Almela, M.: «Ulises en el laberinto. La estructura de Presentimientos, de Clara Sánchez», Tejiendo el mito 13-30.

Amendola, St.: «Due citazioni euripidee (Or. 420 e fr,. 979 Kn.) nel De sera numinis vindicta: riflessioni sulle prime traduzioni a stampa», Musa graeca tradita 149-166.

ÁngEl y EsPINós, J.: «El comentario de Francisco Vallés In libros Hippocratis de morbis popularibus: contexto histórico y antecedentes», Minerva 24, 2011, 195-208.

Angioni, M.C.: «L'Orestea nell'edizione di Robortello da Udine: alcuni casi di metafora e griphos», İtaca 27, 2011, 111-131.

AsEnSI, J.M.: Layos: la historia de un mito griego. Novela histórica. 1 atrchivo de Internet. Madrid, Evohé, 2011.

Ballesteros, J.R.: ««Facinerosi et perditi»: miradas humanistas sobre la antigua Grecia y sus lamentables (y locuaces) habitantes», Grecia ante los imperios 393-402.

Barnés VÁzquez, A.: «Antígona, Hamlet, Odiseo y Don Quijote: una comparación», EH 33, 2011, 73-80.

Bartolotti, A.: Mitología griega y romana. Dioses, héroes, semidioses y monstruos. Traducción de E. Coll. Barcelona, Swing, 2011.

Bergua Cavero, J.: «Estudios clásicos y barbarie (glosas a un libro de A. Barico)», $\Delta \tilde{\omega} \rho o v$

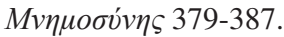

- «La traducción musical de los clásicos en el Renacimiento: antecedentes, presupuestos y logros de una práctica secular», Musa graeca tradita 13-24.

Blanch González, E. - Gómez García, C.: Acercándonos a los mitos a través de la iconografía urbana: de Cibeles a Atocha. Madrid, C.E.R.S.A., 2011.

Businarolo, L.: «L'Edizione eschilea del 1557: il contributo di Henri Estienne», İtaca 27, 2011, 133-153.

Caballero, R.: «Quevedo traductor de Plutarco en la Doctrina estoica: las paradojas de los estoicos y las fantasías de los poetas», Musa graeca tradita 207-222. 
Caldini Montanari, R.: «L' Orsa Minore e l'ora della notte in Arato (e in Cervantes)», Studia mystica, magica et mathematica 453-468.

CAmacho Rojo, J.M.: «La tradición clásica en las literaturas hispánicas e hispanoamericanas del siglo xx Bibliografía analítica II: 2006-2011 (Primera parte)», FI 22, 2011, 217-266.

Cano Alonso, P.L.: «Géneros cinematográficos y mundo antiguo», El cine de romanos en el siglo XXI 59-77.

CARAmico, A.: «O machinatrix lynce versipellior»: nota alla traduzione latina di Xylander di un frammento tragico (fr. trag. adesp.349 S.-K.), tràdito da Plutarco, De audiendis poetis 160D 8-9», Musa graeca tradita 181-192.

Carmona Centeno, D. - Martens, H.: «300: Apuntes sobre la adaptación al cine de la novela gráfica de Miller», Thamyris 2, 2011, 23-48.

Correia Martins, A.I.: «A recepção do motivo felicitas vera $\&$ falsa de Plutarco no tratado de filosofia moral de frei Luís de Granada», Plutarco transmisor 533-544.

Daneloni, A.: «Eschilo e la tradizione eschilea nel laboratorio filologico di Angelo Poliziano», İtaca 27, 2011, 81-101.

Díez Platas, F.: «A través de Ovidio: el viaje del río Aqueloo a occidente», Grecia ante los imperios 377-392.

Duplá Ansuategui, A.: «Nota sobre el cine de romanos» en el siglo XXI», El cine de romanos en el siglo XXI 91-109.

— «Materiales para una bibliografía sobre el cine de romanos» en el siglo XXI», El cine de romanos en el siglo XXI 111-121.

El camino de los mitos, I-IV. 4 vols. Ilustraciones de S. Delgado. Madrid, Evohé, 2011.

Emberger, B.L.: «La Tradición Clásica en la novela Phädra (1885) de Malwida von Meysenbug», FI 22, 2011, 7-31.

- Reescrituras del mito de Fedra en lengua alemana. Tesis doctoral. Granada, Universidad de Granada, 2011.

EnCARnaÇão, J. d': «Viver, filosofar... viver!», Homenaje a Juan José Moralejo 165-174.

EsCOLÀ, J.M.: «La interferència del cristianisme en la transmissió del món antic», Informació $i$ comunicació a Grècia i Roma 147-163.

Essissima, M.-Y.: «Lectura mitocrítica de Femme nue, femme noire, de Calixte Beyala y El llanto de la perra, de Guillermina Mekuy», Tejiendo el mito 31-52.

Fernández Ariza, G.: «El mito y la fábula en Pedro Páramo de Juan Rulfo», $\Delta \tilde{\omega} \rho o v$

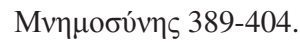

FERnÁNDEZ LóPEz, C.: La sombra del ‘ámbar’, el ‘carámbano’ y otros añicos», Homenaje a Juan José Moralejo 271-281.

Floristán ImízCOZ, J.M.: «Nuevos apuntamientos para una bio-bibliografía de Pedro de Valencia: dos memoriales inéditos», Homenaje a Juan José Moralejo 283-292.

FREY, H.: «La reinvención nietzscheana de la Antigüedad griega. El periodo arcaico como contraimagen de la época clásica griega», Estudios Nietzsche 11, 2011, 27-40.

Frezzato, D.: «Paseo ameno por el Parnaso», Imágenes modernas del mundo antiguo 127-148.

Gamechogoicoechea Llopis, A.: El mito de Orfeo en la literatura barroca española. Valladolid, Universidad, 2011.

García Gual, C.: «Nietzsche y Epicuro», Estudios Nietzsche 11, 2011, 41-52.

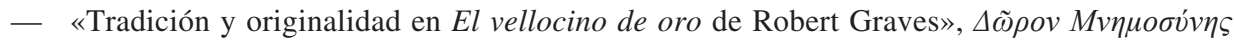
405-412.

García JuRAdo, F.: «Viajes por una historia imaginaria de la literatura grecolatina en el siglo XX», Imágenes modernas del mundo antiguo 13-44.

García-Hernández, B.: «Fraseología e iconografía en la fachada de la Universidad de Salamanca. Alejandro y la ocasión», Sabiduría simbólica y enigmática 353-374. 
García-SÁnchez, M.S.: «Démeter y Perséfone: mito y narrativa en la poesía de Michèle Roberts»; Ph.Canar.16-17, 2010-2011, 43-62.

Garrido GonzÁlez, E.: «Una película de romanos: Ágora de Alejandro Amenábar. Asesoría y licencia histórica», El cine de romanos en el siglo XXI 79-89.

Gilabert i BARberÀ, P.: «Veneno sin antídoto para el Sócrates histórico y la tragedia barroca en El verí del teatre (El veneno del teatro) de Rodolf Sirera: una dosis extrema de sadismo para atajar los excesos de la ficción teatral», EClás.139, 2011, 111-136.

González Galicia, R.: «Conversando con Agustín García Calvo: «no se puede de verdad manejar la lengua: el pueblo está siempre vivo», Methodos 0, 2011.

González García, F.J. - López BarJa de Quiroga, P.M.: «Grecia desde el imperio (americano): la obra de Victor Davis Hanson», Grecia ante los imperios 415-426.

González González, M.: «La Olímpica I de Píndaro en la versión de Fray Luis», Musa graeca tradita 35-52.

GonZÁLez ManJarrés, M.Á.: «El humanismo español: un paisaje y sus figuras. Presentación», Minerva 24, 2011, 13-16.

GuZmán, H.: «Eurípides-Racine-Bruckner: Tres enfoques de un mismo enfrentamiento», Tejiendo el mito 91-110.

— «La ópera King Priam de Tippett: de la épica homérica al drama musical», Minerva 24, 2011, 239-267.

HAmesse, J.: «Los florilegios filosóficos, instrumentos de trabajo de los intelectuales a finales de la Edad Media y en el Renacimiento», EClás.139, 2011, 7-32.

Herrero Ingelmo, M.C. - Montero Cartelle, E.: «El complejo de Antígona y el complejo de Ismene», Homenaje a Juan José Moralejo 349-354.

Lage Cotos, E.: «Autores griegos en Celestina comentada: Unas notas», Homenaje a Juan José Moralejo 369-383.

Lapeña Marchena, O.: «Algunas reflexiones acerca del tratamiento cinematográfico de las guerras médicas», Grecia ante los imperios 427-438.

- «Hacia un pasado común. El cine y la uniformizacion de la antigüedad clásica. Apuntes para su estudio», Methodos 0, 2011.

Lillo Redonet, F.: «Una de romanos: imágenes de la antigüedad en el cine», Imágenes modernas del mundo antiguo 103-125.

LóPEZ FÉrez, J.A.: «Anotaciones sobre la tradición clásica en Jovellanos», Minerva 24, 2011, 209-238.

Macías Villalobos, C.: «El simbolismo de la oveja y su presencia en la obra de Picasso», Virtuti magistri honos 187-235.

Martos Montiel, J.F.: «Autocensura en la traducción de los Idilios de Teócrito cum scholiis de Vicente Mariner», Musa graeca tradita 53-84.

Martínez Díez, A.: «Tras las huellas de Pegaso: De Alfonso X el Sabio al final del siglo Xvi»,

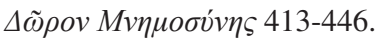

Martínez Fernández, I.: «Marina Tsvetáieva frente al mito de la Amazona», Tejiendo el mito 139-148.

Martínez Hernández, M.: «Plutarco transmisor de las Islas de los Bienaventurados y su recepción en la historiografía canaria (ss. XVI-XIX)», Plutarco transmisor 545-568.

Martínez Martín, J.J.: «Ifigenia de Teresa de la Parra: ¿Una revisión conservadora del mito?», Tejiendo el mito 149-160.

Martínez-FAlero, L.: Narciso en España. De los orígenes a la desmitificación del mito. Madrid, Ediciones Clásicas, 2011.

Mestre, F.: «Interpretatio romana. Grècia i Roma: visions creuades», Informació i comunicació a Grècia i Roma 131-146. 
Montero DíAz, J.: «Historia y cine: hablando en presente», El cine de romanos en el siglo XXI $17-29$.

Morales Ortiz, A.: «Mujeres del mito en Yannis Ritsos. Notas sobre Helena», $\Delta \tilde{\omega} \rho o v$

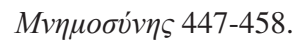

Moreno, A.: «Los conflictos de una heroína trágica: la versión de Medea de Fermín Cabal», Tejiendo el mito 161-176.

Morey Farré, J.M.: «¿Un juego de niños? El Después de Nietzsche de Giorgio Colli», Estudios Nietzsche 11, 2011, 53-66.

MüLler, E.: «Diálogo crítico de Nietzsche con Platón», Estudios Nietzsche 11, 2011, 67-82.

Narro Sánchez, A.: «Los valores de la buena mujer en Plutarco a través del De Institutione feminae christianae de Luis Vives», Plutarco transmisor 569-584.

Nietzsche, F.: El naixement de la tragèdia. Introducció de J. Pòrtulas. Traducció de M. Carbonell. Barcelona, Adesiara, 2011.

NúÑEz GonZÁLEZ, J.M.: «Las clases de Pedro Juan Núñez (_1602) en la Universidad de Zaragoza», Virtuti magistri honos 353-365.

Ormazabal Seviné, M.J. - Navarrete Orcera, A.: Frases célebres y anécdotas de los griegos antiguos. Madrid, Cultivalibros, 2011.

PACE, G.: «La traduzione di Eschilo di Saint-Ravy: il caso dei Persiani, Musa graeca tradita 131-148.

Pagliaroli, S.: «Per la Fortuna di Eschilo nell'umanesimo», İtaca 27, 2011, 57-80.

PAolucci, P.: «Echi classici e tardoantichi in alcuni versi orfici di due poeti vittoriani», Myrtia 26, 2011, 243-263.

Pau Pedrón, A.: Las ninfas de Barcelona. Madrid, Trotta, 2011.

Pedrero, R.: «Heroínas trágicas: del mito a la literatura actual», Tejiendo el mito 199-212.

Pérez Jiménez, A.: «De nuevo el Temístocles de Gracián / Enzinas de 1551. ¿Una traducción revisada?», Plutarco transmisor 585-598.

— «Sí, el Quevedo del Anacreón, helenista», Musa graeca tradita 103-130.

— , Volpe Cacciatore, P.: «Musa graeca tradita / Musa graeca recepta», Musa graeca tradita $7-12$.

Pérez Martín, I.: «El helenismo en la España moderna: libros y manuscritos griegos de Francisco de Mendoza y Bovadilla», Minerva 24, 2011, 59-96.

Pino Campos, L.M.: «La presencia de Plutarco en la obra de José Ortega y Gasset», Plutarco transmisor 599-620.

Pons Tovar, M.: «Música y letra en griego moderno para la poesía de Safo», Thamyris 2, 2011, 159-168.

Popa-Liseanu, D.: «El mito de Proserpina en la vida y obra de la Princesa Bibesco», Tejiendo el mito 213-228.

Pous i Mas, M.T.: El metge d'Atenes. Una novel.la sobre l'art de viure a la Grècia d'Hipòcrates. Palma de Mallorca, Moll, 2011.

Prieto Arciniega, A.: «Alejandro Magno: el cine», El cine de romanos en el siglo XXI 31-58.

RAMÓn PALERM, V.: «La herencia grecolatina en tres autores centroamericanos: Gómez de Ave-

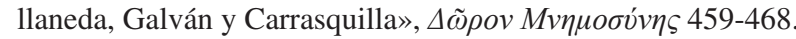

— «Plutarco y Juan de Pineda», Plutarco transmisor 621-632.

REDONDO, J.: «Sobre la recepción de Plutarco en el primer cuarto de siglo xv: el Memorial del pecador Remut de Felip de Malla», Plutarco transmisor 633-644.

RiberA, J.M.: «Maragalliana: Nausica entre Nausícaas», Tejiendo el mito 229-246.

Rioja Nieto, A.: «Los antiguos y la ciencia contemporánea de la naturaleza», Imágenes modernas del mundo antiguo 77-102.

Romero Recio, M.:» Grecia ante Egipto en la historiografía española de los siglos XVIII y XIX», Grecia ante los imperios 403-414. 
RuIz Pérez, Á.: «Santiago Usoz, catedrático en Compostela a mediados del XIX», Homenaje a Juan José Moralejo 509-522.

SÁnchez Marín, J.Á.: «Los juegos griegos y la Poética de J.C. Escalígero», Cal.Ren.11, 2010, 173-188.

SANCHIS LlopIS, J.: «El mundo clásico en obras satíricas de la literatura en castellano del siglo $\mathrm{XV} \gg, S P h V$ 13, 2011, 369-384.

SAnfilippo, M.: «Antígona en la cultura italiana: de Elsa Morante a Mario Martone», Tejiendo el mito 247-258.

Santana Henríquez, G. - Morales Díaz, L.M.: «Apolo, Atlante y las sirenas en la poesía de

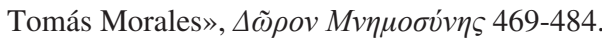

SANTINI, C.: «La reflexión sobre las religiones mistéricas en la filosofía de Nietzsche», Estudios Nietzsche 11, 2011, 83-98.

SEOAne Rodríguez, M.A.: Como una sólida fortaleza: los sabios griegos desenmascarados según el autor de la Cohortatio ad graecos», Sabiduría simbólica y enigmática 221-236.

Silva, M.F.: «Antonio José da Silva, Os encantos de Medeia. A magia em cena», Studia mystica, magica et mathematica 406-409.

Solana Pujalte, J.: «Erratas y correcciones manuscritas de autor en la traducción latina de la Política de Aristóteles de Juan Ginés de Sepúlveda editada por Michel de Vascosan (París, 1548)», CFCL 31, 2011, 293-309.

Stadter, P.A.: «Plutarch in Alexander Hamilton?s pay book», Plutarco transmisor 645-656.

TAngA, F.: «Una citazione euripidea nel Mulierum virtutes di Plutarco: osservazioni sulle traduzioni di età umanistica», Musa graeca tradita 167-180.

TAufer, M.: «Prometheus Vinctus di Jean Dorat: qualche stravaganza congetturale», İtaca 27, 2011, 103-109.

Tavonatti, P.: «Il Contributo di Francesco Porto alla filologia eschilea», Ìtaca 27, 2011, $155-164$

Tedeschi, C.: «Thomas Stanley ed i marginalia al testo di Eschilo», İtaca 27, 2011, 165-182.

Teodoro, J.L.: «El país de Potu o el regne de la raó. Un fragment del Nicolai Klimii iter subterraneum (1741) de Ludvig Holberg», SPhV 13, 2011, 385-401.

TORrione, M.: Alejandro, genio ardiente. El manuscrito de Cristina de Suecia sobre la vida y hechos de Alejandro Magno. Madrid, Machado Grupo de Distribución, 2011.

Tovar, A.: En el primer giro. Estudios sobre la antigüedad. Un libro sobre Platón. Barcelona, Planeta DeAgostini, 2011.

Vela TeJada, J.: «Pervivencia de la tradición clásica en el teatro musical español del XVIII»,

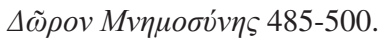

Verdía Barbará, B.: La antropología victoriana y el estudio de la religión griega. Tesis Doctoral. Santiago de Compostela, Universidad, 2011.

- «Jane Ellen Harrison: una mujer en el mundo académico victoriano», Gallaecia 30, 2011, 195-209.

VIGorito; M.: «Sul De audiendis poetis di Plutarco: citazioni omeriche nelle traduzioni umanistiche», Musa graeca tradita 25-34.

Villalba Babiloni, T.E.: Recepción del legado clásico griego en la cultura alemana de finales del siglo XVIII y principios del XIX. Tesis Doctoral. Castellón, Universitat Jaume I, 2011.

Villena, L.A.: Diccionario de mitos clásicos para uso de modernos. Madrid, Gredos, 2011.

Volpe Cacciatore, P.: «Citazioni poetiche nel De liberis educandis in alcune traduzioni umanistiche», Musa graeca tradita 193-206.

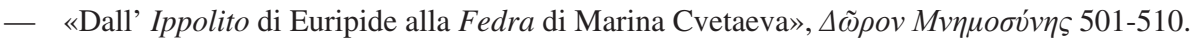

Voutsa, S. :»Constantinos Cavafis lee a Plutarco: historia, ironía y drama», Plutarco transmisor 657-674. 
WulfF Alonso, F.: «Usos y manipulaciones políticas de la antigüedad: nacionalismos de aquí y allá», Imágenes modernas del mundo antiguo 45-76.

\section{Diccionarios. Repertorios. Otros instrumentos}

CAmacho Rojo, J.M.: «La tradición clásica en las literaturas hispánicas e hispanoamericanas del siglo xx Bibliografía analítica II: 2006-2011 (Primera parte)», FI 22, 2011, 217-266.

Duplá Ansuategui, A.: «Materiales para una bibliografía sobre el cine de romanos» en el siglo XXI», El cine de romanos en el siglo XXI 111-121.

García Santos, A.A.: Diccionario del Griego Bíblico. Setenta y Nuevo Testamento. Estella, Verbo Divino, 2011.

Rodríguez Somolinos, H.: «Publicaciones sobre filología griega en España (2010)», Epos 27, 2011, 363-410.

\section{DidÁCTICA}

Alcalde-Diosdado Gómez, A.: «La necesidad de renovación didáctica de las lenguas clásicas. Una nueva propuesta metodológica», Methodos 0, 2011.

Amaya Chávez, V.: «Sexo y muerte. Dos historias, una misma consecuencia», Thamyris 2, 2011, 67-80.

Cano, P.L. - Martínez Gázquez, J.: «Sobre textos clásicos y pintura: algunas observaciones», Methodos 0, 2011.

Carmona Centeno, D. - Martens, H.: «300: Apuntes sobre la adaptación al cine de la novela gráfica de Miller», Thamyris 2, 2011, 23-48.

Díaz CARretero, J.J.: «El latín y el griego clásicos en las marcas comerciales: algunos ejemplos», Thamyris 2, 2011, 15-21.

Díez Fernández, O. - Inclán, L., Giralt, S. - Pérez Vilariño, Á.: «Chiron, cultura clásica 2.0», Methodos 0, 2011.

Domínguez Alonso, A.C. - González Rodríguez, A.: «La vida cotidiana en el Ática antigua a través de la cerámica», Thamyris 2, 2011, 169-205.

EsPinar OJEDA, J.L.: «Una aproximación a la música griega antigua», Thamyris 2, 2011, 141-157.

Foulkes, I.: Griego del Nuevo Testamento. 1 archivo de Internet. Barcelona, Clie, 2011.

GiRALT, S.: «Noves estratègies de seducció: estudis clàssics i Internet a secundària», Methodos $0,2011$.

Husillos García, M.L.: «Herramientas para la enseñanza de la Cultura Clásica» Thamyris 2, 2011, 3-14.

LapeÑa Marchena, Ó.: «Hacia un pasado común. El cine y la uniformizacion de la antigüedad clásica. Apuntes para su estudio», Methodos 0, 2011.

Lesage Gárriga, L. - Navarrete Orcera, A.: Crónicas mitológicas. Un año de Cultura Clásica. Madrid, Cultivalibros, 2011.

MAcías, C.: «Las clásicas y la enseñanza virtual: algunas experiencias», Methodos 0, 2011.

Navarrete Orcera, A.R.: «La iconografía de las Traquinias de Sófocles», Thamyris 2, 2011, 105-140.

Ormazabal Seviné, M.J. - Navarrete Orcera, A.: Frases célebres y anécdotas de los griegos antiguos. Madrid, Cultivalibros, 2011.

Lillo Redonet, F.: «Enseñar la civilización bizantina a través del cine», Methodos 0, 2011.

Martín Algarra, A.M. - Zamora Manzanares, A.M.: Didáctica de la morfología griega. Murcia, DM, 2011. 
Navarro GonzÁlez, J.L. - Rodríguez JimÉnez, J.M.: Griego, prueba acceso universidad: fase específica voluntaria. Madrid, Anaya, 2011.

Palladium (latín, griego y culturas clásicas ESO y bachillerato). 1 CD-ROM. Ministerio de Educación, Cultura y Deporte. Subdirección General de Documentación y Publicaciones, 2011.

RodríGuez GonzÁLEz, L.: Griego I. Valencia, Educàlia, 2011.

Septién del Coso, J.A.: Griego bíblico al alcance de todos. 1 archivo de Internet. Barcelona, Clie, 2011.

Tovar Paz, F.J.: «Posibilidades didácticas y de investigación sobre mitos en el cine (excepción hecha del género peplum y las adaptaciones literarias)», Methodos 0, 2011. 